\title{
Near-Infrared Chemiluminescent Probe for Real-Time Monitoring Singlet Oxygen in Cells and Mice Model
}

Mingwang Yang ${ }^{\mathrm{a}}$, Junwei Zhang ${ }^{\mathrm{a}}$, Doron Shabat ${ }^{\mathrm{b}}$, Jiangli Fan*a, Xiaojun Peng ${ }^{\mathrm{a}}$

a State Key Laboratory of Fine Chemicals, Dalian University of Technology, 2 Linggong Road, Dalian, 116024, P.R. China.

b School of Chemistry, Faculty of Exact Sciences, Tel Aviv University, Tel Aviv 69978 Israel.

*E-mail: (J. Fan) fanj1@,dlut.edu.cn 


\section{Materials and Instruments.}

All chemical reagents and related solvents were purchased form manufacturers and applied directly. 2,2',4,4'-Tetrahydroxybenzophenone was purchased from Energy Chemical. When performing flash column chromatography, we used Silica gel (200300 mesh) purchased from Qingdao Haiyang Chemical Co., Ltd. Bruker NMR spectrometers were applied for testing the ${ }^{1} \mathrm{H}$ NMR and ${ }^{13} \mathrm{C}$ NMR spectra of all compounds and the chemical shifts $(\delta)$ were expressed as parts per million (ppm). The pH-meter Phs-3C and Varioskan LUX Multimode Microplate Reader were applied to detect the $\mathrm{pH}$ values and cytotoxicity. The BALB/c mice were purchased from Dalian Medical University. All the animal experiments were carried out in accordance with the relevant laws and guidelines approved by Dalian Medical University Animal Care and Use Committee.

MVP was synthesized according to the reference S1.

\section{Chemiluminescence response of CL-SO to ${ }^{1} \mathrm{O}_{2}$}

A certain amount of probe powder was accurately weighed and placed in a 10-ml volumetric flask, and DMSO was added to obtain the concentration of probe stock solution at $2 \mathrm{mM}$.

Methylene blue (MB): $7.48 \mathrm{mg}$ methylene blue was dissolved in $10 \mathrm{~mL}$ deionized water to obtain $2 \mathrm{mM}$ MB stock solution.

The ROS and other analytes were prepared according to the previous reports ${ }^{\mathrm{S}-\mathrm{S} 5}$. Stock solutions of $\mathrm{HOCl}(50 \mathrm{mM})$ and $\mathrm{H}_{2} \mathrm{O}_{2}(50 \mathrm{mM})$ were prepared by directly diluting the commercial compounds with ultra-pure water.

TBHP: A solution of $32 \mathrm{mg}$ TBHP (70\%) was diluted to $10 \mathrm{~mL}$ with ultra-pure water to obtain a $50 \mathrm{mM}$ TBHP stock solution.

TBO $: 50 \mathrm{mM}$ TBHP solution was mixed with the same concentration of ferrous sulfate solution to obtained $50 \mathrm{mM}$ TBO$\cdot$ stock solution.

$\mathrm{O}_{2}: 35.5 \mathrm{mg}$ potassium superoxide was dissolved in $10 \mathrm{~mL}$ DMSO to obtain $\mathrm{O}_{2}{ }^{-}$stock solution with a concentration of $50 \mathrm{mM}$.

$\cdot \mathrm{OH}: 50 \mathrm{mM} \cdot \mathrm{OH}$ stock solution was prepared by Fenten reaction between $50 \mathrm{mM}$ ferrous sulfate solution and $500 \mathrm{mM}$ hydrogen peroxide.

${ }^{1} \mathrm{O}_{2}$ : A photosensitizer methylene blue (MB) under the red LED light $(620-630 \mathrm{~nm})$ irradiation $(20 \mathrm{~mW})$; the reaction of $\mathrm{NaClO}_{4}$ and excessive $\mathrm{H}_{2} \mathrm{O}_{2}$ can produce ${ }^{1} \mathrm{O}_{2}$ with a yield of about $100 \%$.

In the test system, $10 \mu \mathrm{M}$ probe CL-SO and $10 \mu \mathrm{M}$ photosensitizer MB were added, and irradiated by $620-630 \mathrm{~nm}$ red LED $(20 \mathrm{~mW})$ for different time, the the chemiluminescence intensity was immediately measured. 
Time attenuation of chemiluminescence intensity. After adding about 100 equivalent ${ }^{1} \mathrm{O}_{2}\left(\mathrm{H}_{2} \mathrm{O}_{2} / \mathrm{NaClO}\right.$ system) to the test system (PBS, $10 \% \mathrm{MeOH}$ and $10 \% \mathrm{FBS}, 10 \mathrm{mM}$, $\mathrm{pH}$ 7.4) containing $10 \mu \mathrm{M}$ probe CL-SO, the chemiluminescence intensity of the probe at $700 \mathrm{~nm}$ were measured on a fluorescence spectrometer. At the same time, chemiluminescence imaging was carried out on the small animal imaging system.

Selectivity. Various interferences including various amino acids (Val, Lys, Arg, Phe, Ala, Leu, Trp, Ser, Pro, Thr, Tyr), ions ( $\mathrm{MgCl}_{2}, \mathrm{PbCl}_{2}, \mathrm{Na}_{2} \mathrm{SO}_{3}, \mathrm{NaSCN}, \mathrm{NaClO}_{2}$, $\mathrm{NaHCO}_{3}, \mathrm{NaF}, \mathrm{NaOAc}, \mathrm{Na}_{2} \mathrm{~S}_{2} \mathrm{O}_{3}, \mathrm{NaHSO}_{3}, \mathrm{NaHSO}_{3}, \mathrm{DTT}$, NaHS), reactive oxygen species $\left(\mathrm{H}_{2} \mathrm{O}_{2}, \mathrm{ClO}^{-}, \mathrm{TBHP}, \mathrm{TBO} \cdot \cdot \mathrm{OH}, \mathrm{O}_{2}^{-}\right)$are added to all-black 96-well plates containing CL-SO $(10 \mu \mathrm{M})$ and then detect the chemiluminescence intensity. Without special statement, all the concentrations of analytes are at $500 \mu \mathrm{M}$.

\section{Cytotoxicity experiments}

The MTT method was employed to assess the cellular cytotoxicity of CL-SO. Before experiments, MCF-7 cells at a density of $1 \times 10^{4}$ cells/well were seeded into 96-well plates and cultured for $24 \mathrm{~h}$. The cells were divided into two groups. Group A: the fresh culture contained CL-SO over a range of concentrations $(0-30 \mu \mathrm{M})(\mathrm{n}=6)$ to substitute the previous media, and further incubation for $1 \mathrm{~h}$, and then with or without red LED irradiation for $5 \mathrm{~min}$. Group B: the fresh culture contained CL-SO over a range of concentrations $(0-30 \mu \mathrm{M})(\mathrm{n}=6)$ to substitute the previous media, and further incubation for $24 \mathrm{~h}$. After that, $10 \mu \mathrm{L}$ of MTT ( $5 \mathrm{mg} / \mathrm{mL}$ in PBS) was added into per well and incubated another $4 \mathrm{~h}$ of two groups. Finally, $100 \mu \mathrm{L}$ of DMSO was then added

to dissolve formazan. The absorbance at $490 \mathrm{~nm}$ was measured, and the cell viability (\%) was calculated according to the following equation: Viability (\%) $=[\mathrm{OD}$ (sample) - OD (blank)] / [OD (control) - OD (blank)] ×100\%.

\section{Cells uptake fluorescence imaging experiment}

One day before imaging, the cells were detached and were replanted on glass-bottomed dishes and allowed to adhere for 24 hours. MCF-7 cells were incubated with probe CLSO $(10 \mu \mathrm{M})$ for different time $(0,5,10,15,20,25,30,35,40,49,53$ and $60 \mathrm{~min})$, washed with PBS for three times, added fresh culture medium and performed fluorescence imaging on a laser confocal fluorescence microscope (Olympus FV3000). The excitation wavelength is $561 \mathrm{~nm}$, and the fluorescence receiving wavelength is 650-750 nm.

\section{In vivo chemiluminescence imaging experiment}


All the animal experiments were carried out in accordance with the relevant laws and guidelines approved by Dalian Medical University Animal Care and Use Committee. The BALB/c mice purchased from Dalian Medical University.

Chemiluminescence imaging in the abdominal cavity of mice. The mice were anesthetized with chloral hydrate $(5 \%)$ and fixed. Mice in CL-SO group were intraperitoneally injected with $200 \mathrm{~mL}$ PBS $\left(100 \mu \mathrm{M}\right.$ CL-SO). CL-SO $+{ }^{1} \mathrm{O}_{2}$ group: 100 mL PBS (100 mM H $\mathrm{O}_{2}, 100 \mu \mathrm{M}$ CL-SO) followed by injection of $100 \mathrm{~mL}$ PBS (containing $10 \mathrm{mM} \mathrm{NaClO}$ ). CL-SO $+{ }^{1} \mathrm{O}_{2}+\mathrm{NaN}_{3}$ group: $100 \mathrm{~mL}$ PBS $(100 \mu \mathrm{M}$ CL-SO) was injected at the same position before imaging. CL-SO $+\mathrm{NaN}_{3}$ group: $200 \mu \mathrm{L}$ PBS (10 $\mathrm{mM} \mathrm{NaN}_{3}, 100 \mu \mathrm{M} \mathrm{CL}-\mathrm{SO}$ ). Time of exposure: $15 \mathrm{~min}$.

Time-dependent chemiluminescence imaging. Mice were anesthetized with chloral hydrate (mass fraction 5\%) and fixed. $100 \mu \mathrm{L}$ PBS (containing 50\% $\mathrm{MeOH}, 100 \mathrm{mM}$ $\mathrm{H}_{2} \mathrm{O}_{2}, 100 \mu \mathrm{M}$ CL-SO) was injected intraperitoneal simultaneously on both sides, followed by $100 \mu \mathrm{L}$ saline on the left and $100 \mu \mathrm{L}$ PBS (containing $10 \mathrm{mM} \mathrm{NaClO}$ ) on the right. Mice were placed in a small animal imaging system for chemiluminescence time imaging, with a chemiluminescence exposure of $15 \mathrm{~min}$.

\section{Synthesis and characterization of CL-SO}
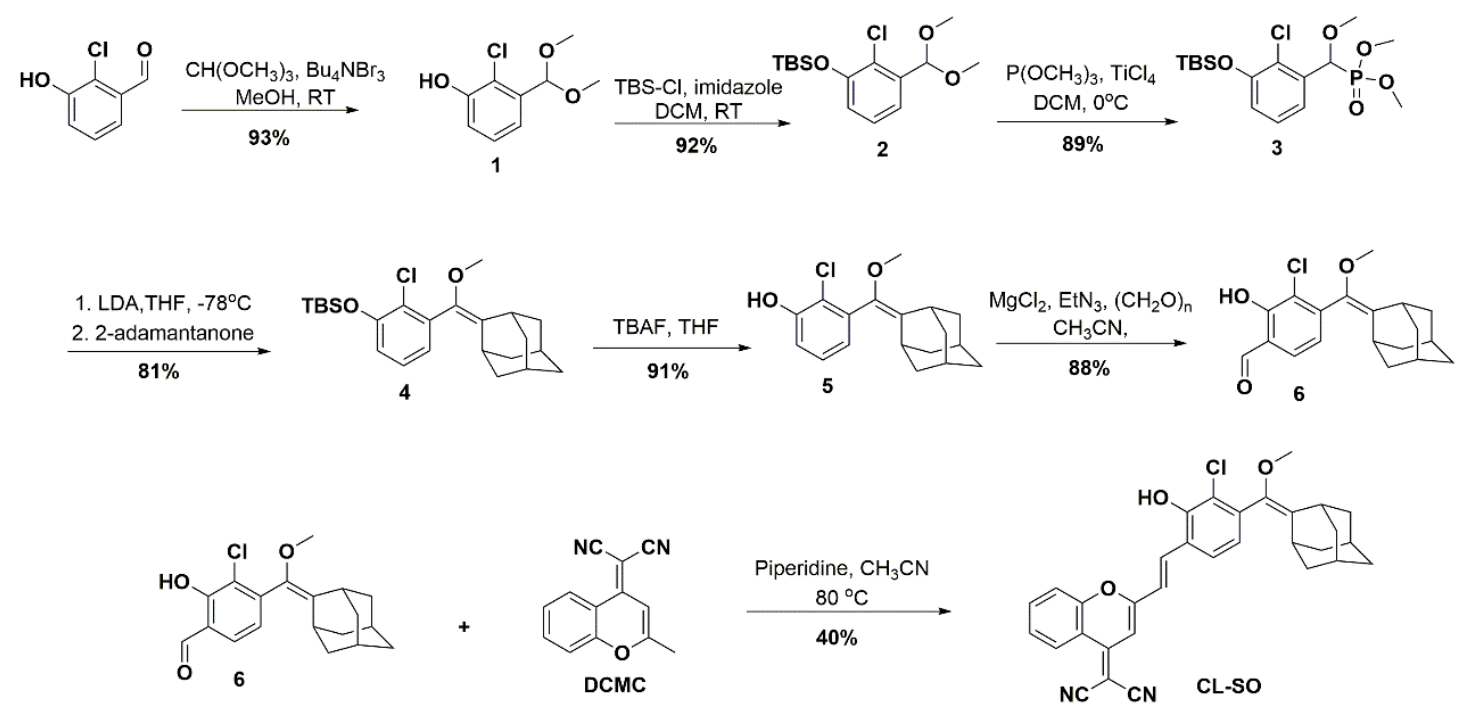

Scheme S1 Synthesis of probe CL-SO

Compounds 1-5, 6, DCMC were synthesized according reference S6, S7 and S8.

CL-SO: Compound 6 (50 mg, $0.15 \mathrm{mmol})$, piperidine $(22 \mu \mathrm{L}, 0.18 \mathrm{mmol})$ and dicyanomethyl chromone (DCMC) (38 mg, $0.18 \mathrm{mmol})$ were dissolved in $5 \mathrm{~mL}$ of $\mathrm{CH}_{3} \mathrm{CN}$. The reaction mixture was stirred at $80^{\circ} \mathrm{C}$ for 1 hour and monitored by TLC (petroleum ether: EtOAc = 3:2). Upon completion, the reaction mixture diluted with EtOAc $(100 \mathrm{~mL})$ and was washed with saturated solution of $0.5 \mathrm{M} \mathrm{HCl}(100 \mathrm{~mL})$ and 
brine, the organic layer was separated and dried over $\mathrm{Na}_{2} \mathrm{SO}_{4}$ and evaporated under reduced pressure. The product was obtained as a brown solid through silica gel column chromatography with petroleum ether: EtOAc (9:1) as the eluent (31.6 mg, yield: 40\%). ${ }^{1} \mathrm{H}$ NMR (400 MHz, $\mathrm{CDCl}_{3}$ ) $\delta(\mathrm{ppm}): 8.92(\mathrm{dd}, J=8.3,1.2 \mathrm{~Hz}, 1 \mathrm{H}), 7.84(\mathrm{~d}, J=16.1 \mathrm{~Hz}$, $1 \mathrm{H}), 7.75(\mathrm{t}, J=7.8 \mathrm{~Hz}, 1 \mathrm{H}), 7.62(\mathrm{~d}, J=8.4 \mathrm{~Hz}, 1 \mathrm{H}), 7.61(\mathrm{~m}, 2 \mathrm{H}), 7.47(\mathrm{~m}, 1 \mathrm{H}), 7.13(\mathrm{~d}$, $J=16.0 \mathrm{~Hz}, 1 \mathrm{H}), 6.92(\mathrm{~s}, 1 \mathrm{H}), 6.60(\mathrm{~s}, 1 \mathrm{H}), 3.34(\mathrm{~s}, 3 \mathrm{H}), 3.29(\mathrm{~s}, 1 \mathrm{H}), 2.16(\mathrm{~s}, 1 \mathrm{H}), 1.98$ $1.78(\mathrm{~m}, 12 \mathrm{H}) .{ }^{13} \mathrm{C} \mathrm{NMR}\left(101 \mathrm{MHz}, \mathrm{CDCl}_{3}\right) \delta(\mathrm{ppm}): 154.30,152.83,151.87,149.46$, $135.80,133.64,132.83,128.91,125.50,124.99,124.84,119.75,117.74,116.88$, $115.73,106.32,76.25,75.74,56.40,36.01,34.90,31.96,30.90,28.77,28.68,28.59$, 26.20, 24.52. HRMS (ES-) (m/z): calcd for $\mathrm{C}_{32} \mathrm{H}_{26} \mathrm{ClN}_{2} \mathrm{O}_{3}: 521.1632$, found: 521.1639 $[\mathrm{M}-\mathrm{H}]^{-}$.

\section{The test spectra and chemiluminescent imaging of CL-SO in vitro and vivo}
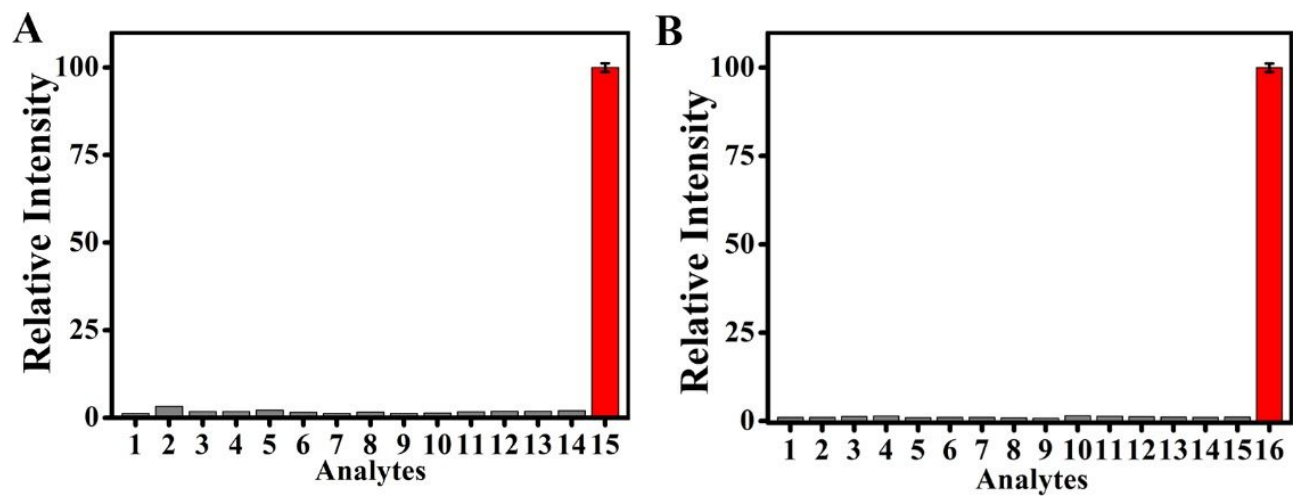

Figure S1 Relative CL intensity of CL-SO $(10 \mu \mathrm{M})$ in presence of different analytes (500 $\mu \mathrm{M}$ )including A: (1) Pro, (2) Tyr, (3) Asp, (4) Ser, (5) Arg, (6) Ala, (7) Leu, (8) Val, (9) Lys, (10) Phe, (11) Trp, (12) Thr, (13) Cys, (14) Glu, (15) ${ }^{1} \mathrm{O}_{2}$; B: (1) $\mathrm{MgCl}_{2}$, (2) $\mathrm{PbCl}_{2}$, (3) $\mathrm{Na}_{2} \mathrm{SO}_{3}$, (4) $\mathrm{NaSCN}$, (5) $\mathrm{NaClO}_{2}$, (6) $\mathrm{NaHCO}_{3}$, (7) NaF, (8) NaOAc, (9) $\mathrm{Na}_{2} \mathrm{~S}_{2} \mathrm{O}_{3}$, (10) $\mathrm{NaHSO}_{3},(11) \mathrm{AgNO}_{3}$, (12) DTT, (13) NaHS, (14) $\mathrm{NaCl}$, (15) $\mathrm{FeCl}_{3}$ (16) ${ }^{1} \mathrm{O}_{2}$ in PBS solution.

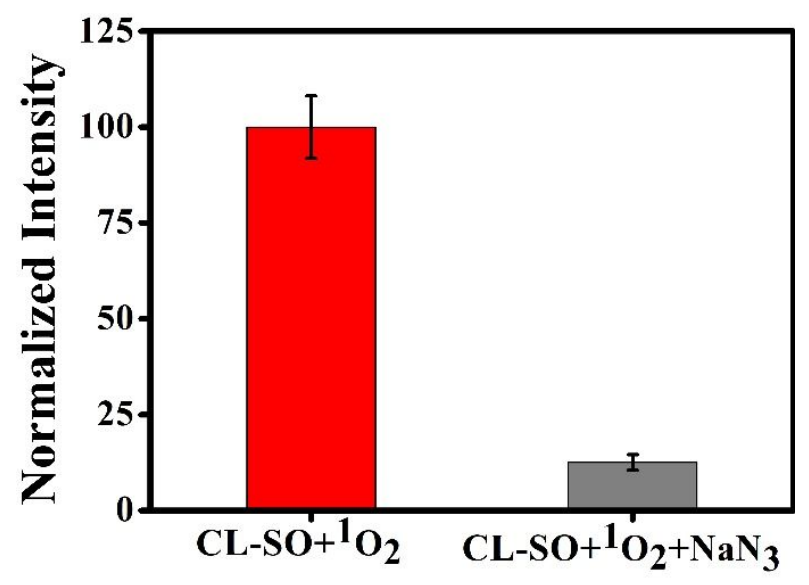


Figure S2 Chemiluminescence signal attenuation in homogenous solution: CL-SO (10 $\mu \mathrm{M})$ was treated with photosensitizer MB $(10 \mu \mathrm{M})$. Chemiluminescence measurements were performed in the presence or in the absence of $\mathrm{NaN}_{3}(1 \mathrm{mM})$.
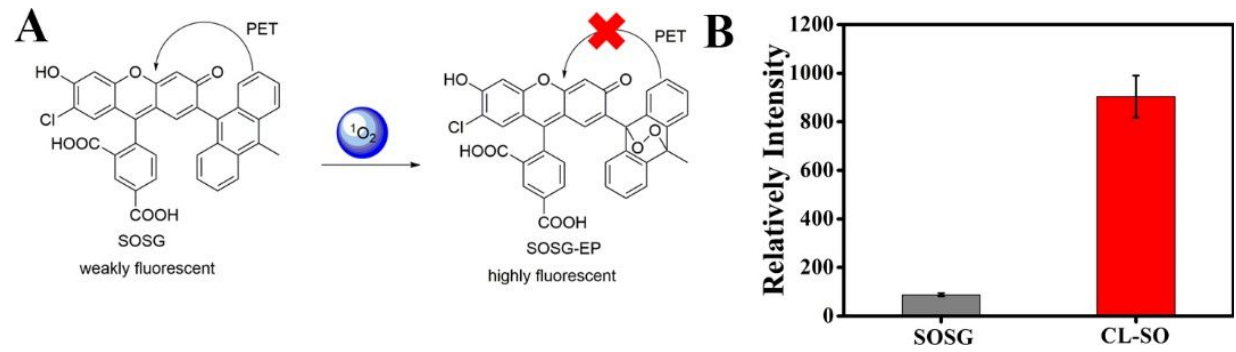

Figure S3 (A) The detection mechanism of SOSG for ${ }^{1} \mathrm{O}_{2}$. (B) The comparison of turnon times for the SOSG $(10 \mu \mathrm{M})$ and CL-SO $(10 \mu \mathrm{M})$ in the presence of ${ }^{1} \mathrm{O}_{2}$ produced by MB.

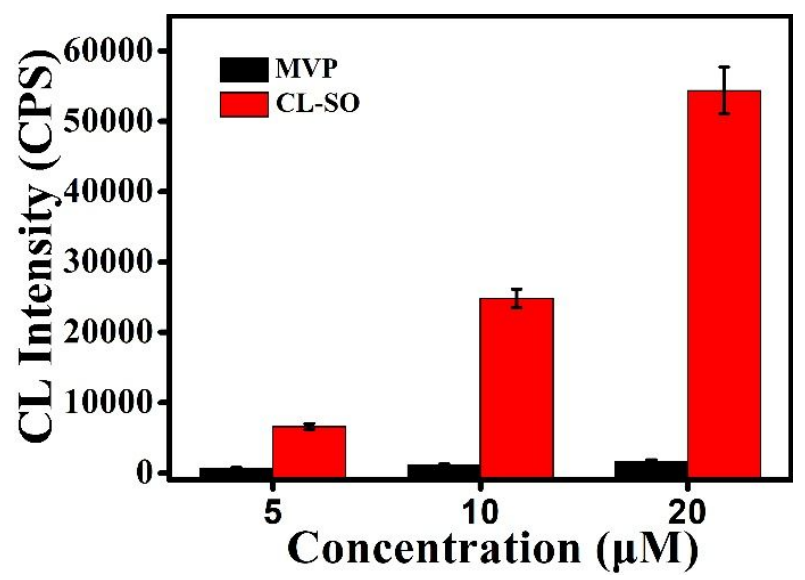

Figure S4 Comparison of the chemiluminescence intensity at different concentrations $(5,10,20 \mu \mathrm{M})$ of CL-SO and MVP in the same conditions. Irradiation with $10 \mu \mathrm{M} \mathrm{MB}$ to produce ${ }^{1} \mathrm{O}_{2}$.

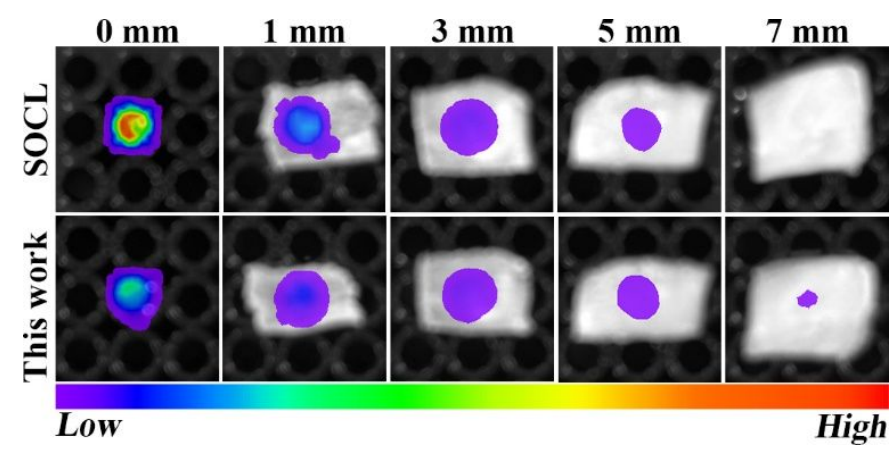

Figure S5 Comparison the tissue penetration depth of CL-SO $(10 \mu \mathrm{M})$ and SOCL $(10$ $\mu \mathrm{M})$ in same conditions, covering different thickness of pork tissue $(0,1,3,5,7,9 \mathrm{~mm})$ in test system. Irradiation with $10 \mu \mathrm{M}$ MB to produce ${ }^{1} \mathrm{O}_{2}$. 

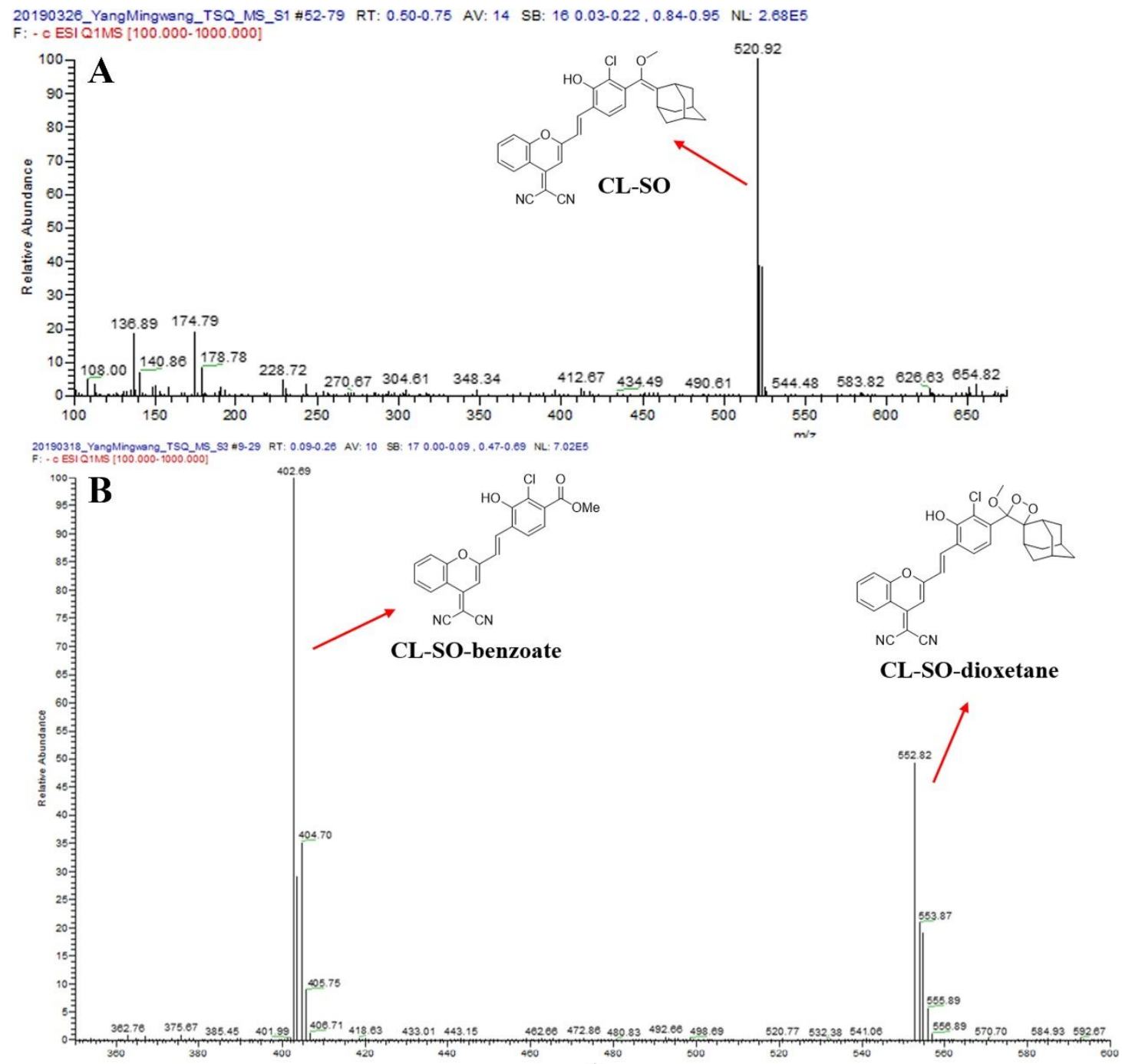

20190313_YangMingwang_TSQ_MS_S2 (2) \#8-28 RT: 0.07-0.26 AV: 11 SB: 18 0.01-0.07, 0.42-0.83 NL: $1.37 E 5$

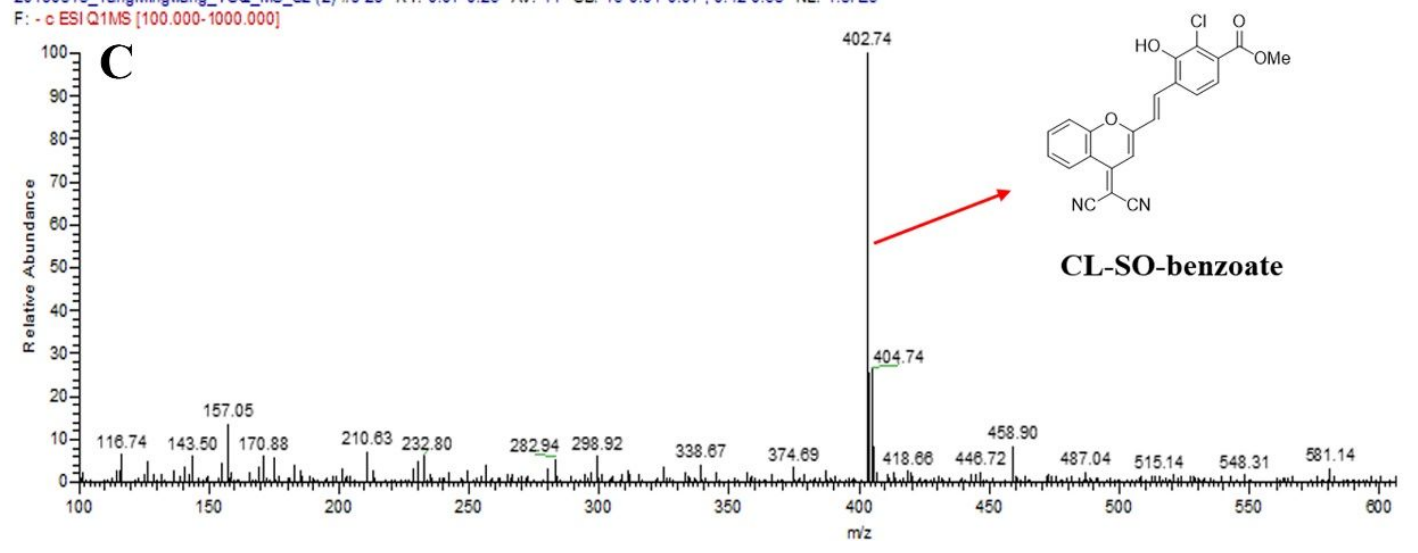

Figure S6 MS analysis of CL-SO chemiluminescent decomposition pathway upon reaction with ${ }^{1} \mathrm{O}_{2}$. (A) CL-SO $(10 \mu \mathrm{M})$; (B) CL-SO $(10 \mu \mathrm{M})$ reacts with ${ }^{1} \mathrm{O}_{2}$ to form dioxetane in $\mathrm{MeOH}$; (C) PBS ( $\mathrm{pH}$ 7.4) was added into group $\mathrm{B}$, and within $1 \mathrm{~h}$ complete decomposition to produce the benzoate ester. 


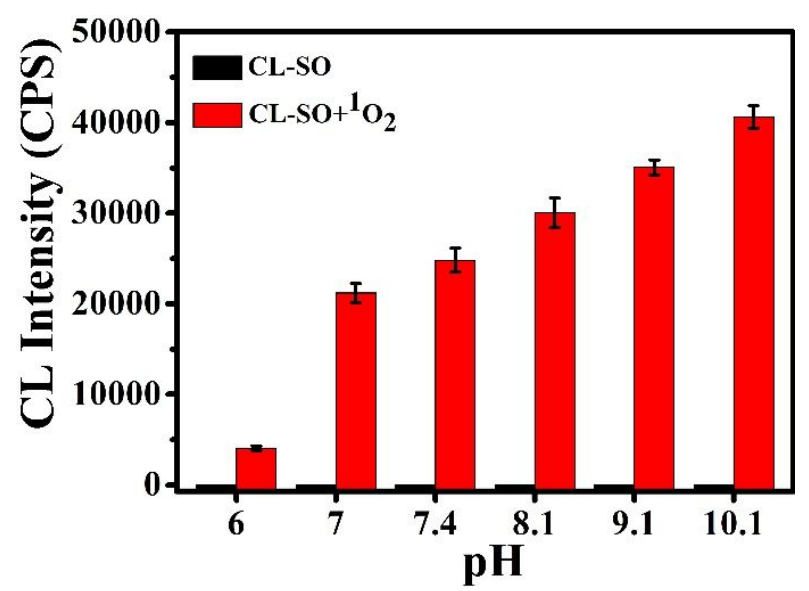

Figure S7 The CL imaging and intensity of CL-SO $(10 \mu \mathrm{M})$ in the presence or absence of ${ }^{1} \mathrm{O}_{2}$ (produced by $\mathrm{MB}$ ) in various $\mathrm{pH}$ ranging 6-10.1 in testing solution.

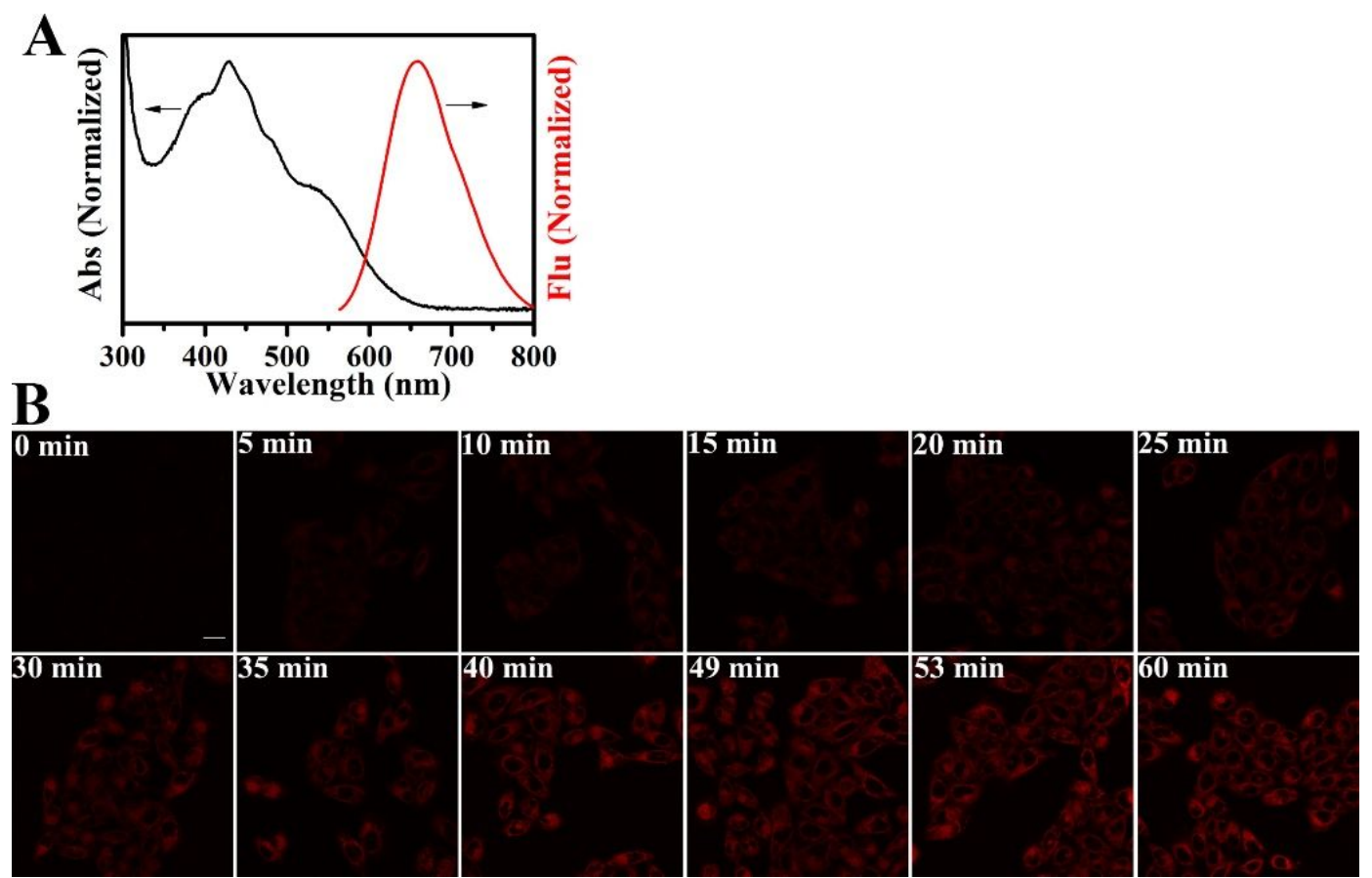

Figure S8 (A) The normalized absorption and fluorescence spectrums of CL-SO. (B) The fluorescence imaging of MCF-7 cells which were incubated with CL-SO $(20 \mu \mathrm{M})$ for different time $(0-60 \mathrm{~min}), \lambda_{\mathrm{ex}}=561 \mathrm{~nm}, \lambda_{\mathrm{em}}=650-750 \mathrm{~nm}$. Scale bar $=20 \mu \mathrm{m}$. 

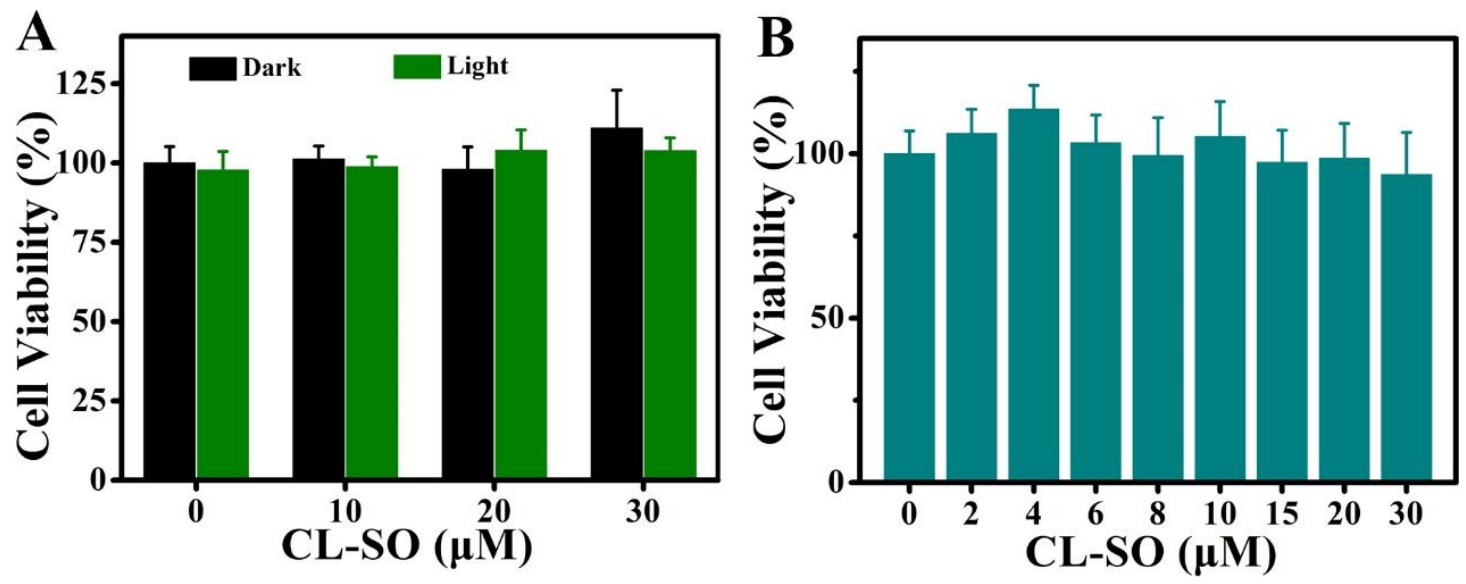

Figure S9 MTT assays of MCF-7 cells. (A) Cells were incubated with probe CL-SO $(0-30 \mu \mathrm{M})$ for $1 \mathrm{~h}$, and then with or without red $(620-630 \mathrm{~nm})$ LED $(20 \mathrm{~mW})$ irradiation for 5 min. (B) Cells were incubated with probe CL-SO $(0-30 \mu \mathrm{M})$ for $24 \mathrm{~h}$ without irradiation.

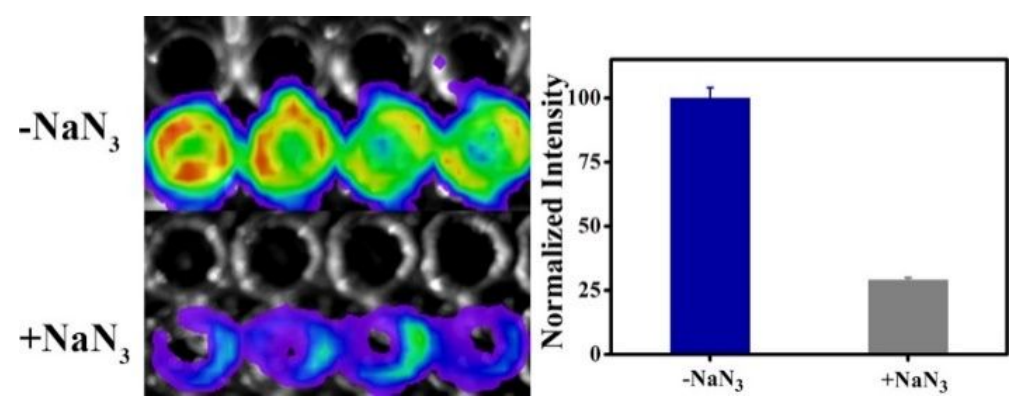

Figure S10 Cells were incubated with MB $(10 \mu \mathrm{M})$, CL-SO $(20 \mu \mathrm{M})$ simultaneously, and then treated with or without $\mathrm{NaN}_{3}(1.0 \mathrm{mM})$, imaging after light treatment. Quantification of chemiluminescent intensity.
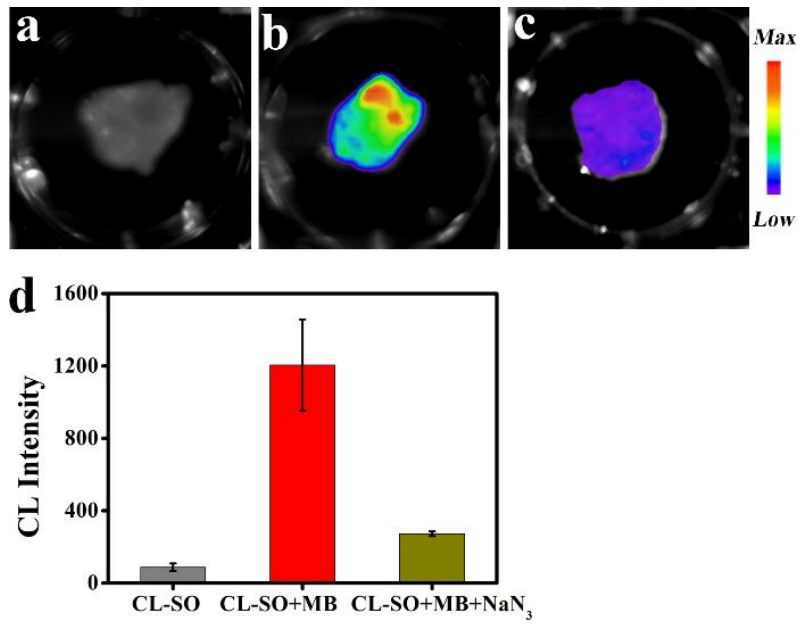

Figure S11 Liver tissues of mice were stained with a: CL-SO $(20 \mu \mathrm{M})$; b: CL-SO $(20$ $\mu \mathrm{M})+\mathrm{MB}(10 \mu \mathrm{M})$; c: CL-SO $(20 \mu \mathrm{M})+\mathrm{MB}(10 \mu \mathrm{M})+\mathrm{NaN}_{3}(5 \mathrm{mM})$ for $1 \mathrm{~h}$ and the chemiluminescent imaging were performed after illumination (red light, 620-630 nm, $20 \mathrm{~mW}$ ). 

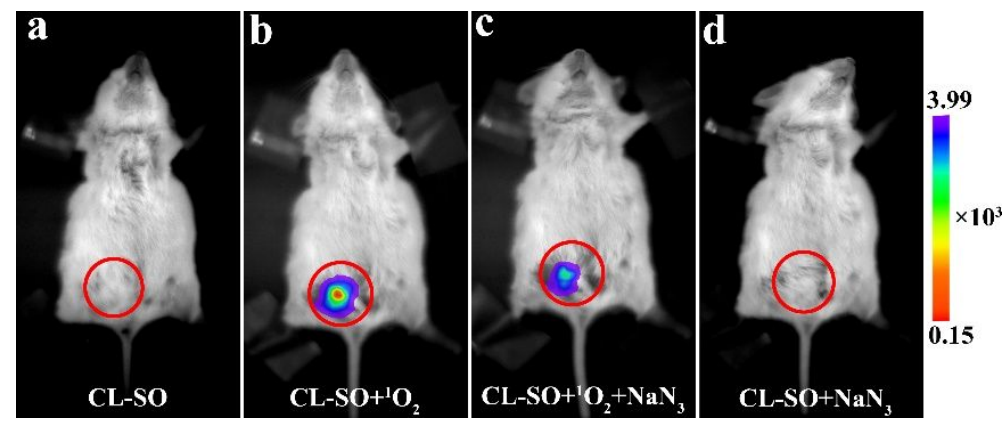

Figure S12 Chemiluminescence imaging and detection of ${ }^{1} \mathrm{O}_{2}$ in mouse abdominal cavity. The conditions were the same as figure 3 .
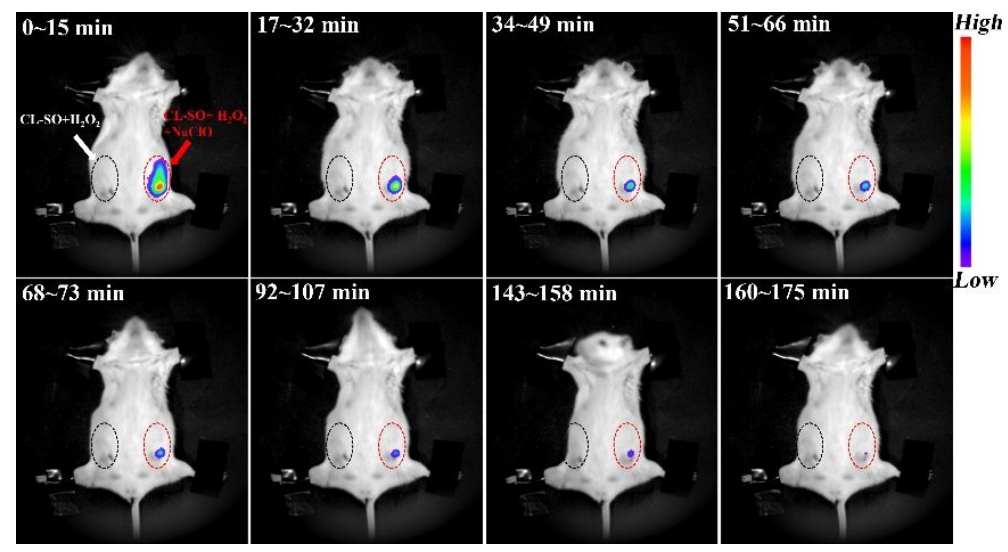

Figure S13 Time-dependent chemiluminescence imaging of CL-SO in the intraperitoneal region of BALB/c mice. First, $100 \mu \mathrm{L}$ each of CL-SO $(100 \mu \mathrm{M})$ and $\mathrm{H}_{2} \mathrm{O}_{2}(100 \mathrm{mM})$ in PBS/MeOH (10 mM, pH 7.4) was injected simultaneously into both sides of the abdomen. Next, $100 \mu \mathrm{L}$ of PBS or $\mathrm{NaClO}(10 \mathrm{mM})$ was injected into the left and right regions before imaging.
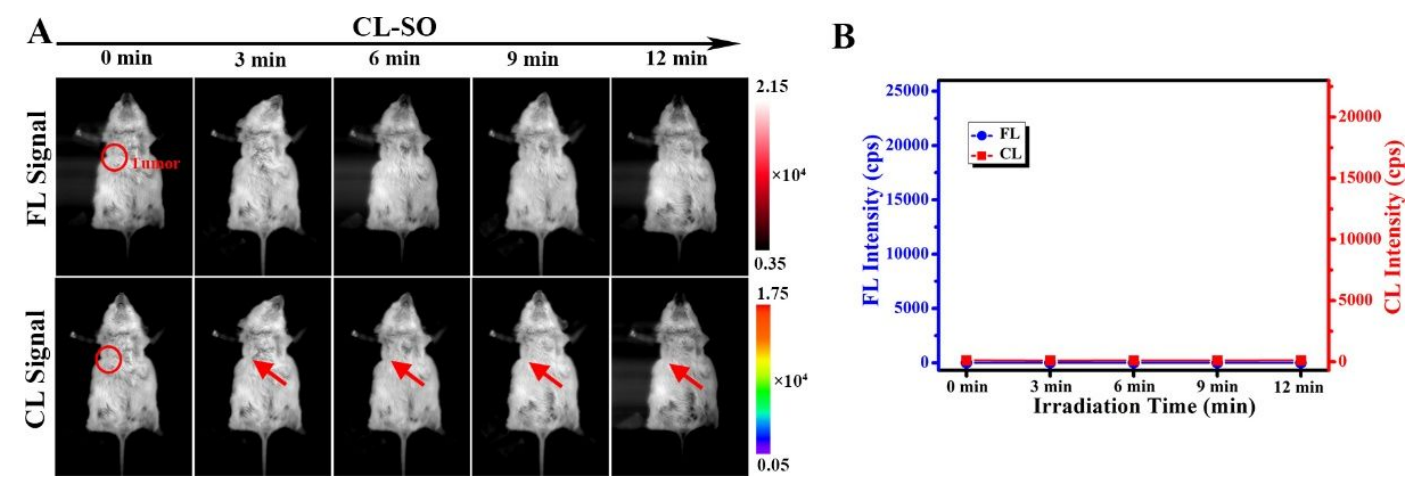

Figure S14 (A) Only CL-SO $(50 \mu \mathrm{M})$ were injected into tumors and the signals were collected via FL and $\mathrm{CL}$ modes after different periods of light irradiation. (B) Quantification of signals intensity in group A. For FL imaging: $\lambda_{\mathrm{ex}}=665 \mathrm{~nm}$, collected at $700 \pm 10 \mathrm{~nm}$. 


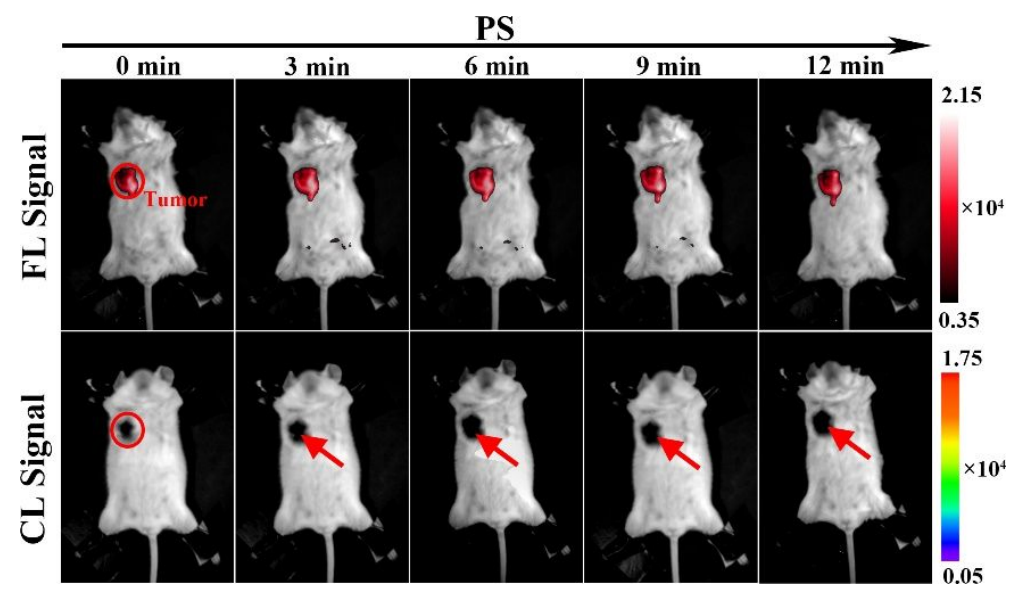

Figure S15 Only MB $(50 \mu \mathrm{M})$ were injected into tumors and the signals were collected via FL and CL modes after different periods of light irradiation. The conditions were the same as figure $4 \mathrm{~A}$.

Figure S16 The spectra of all intermedia and targeted compounds.

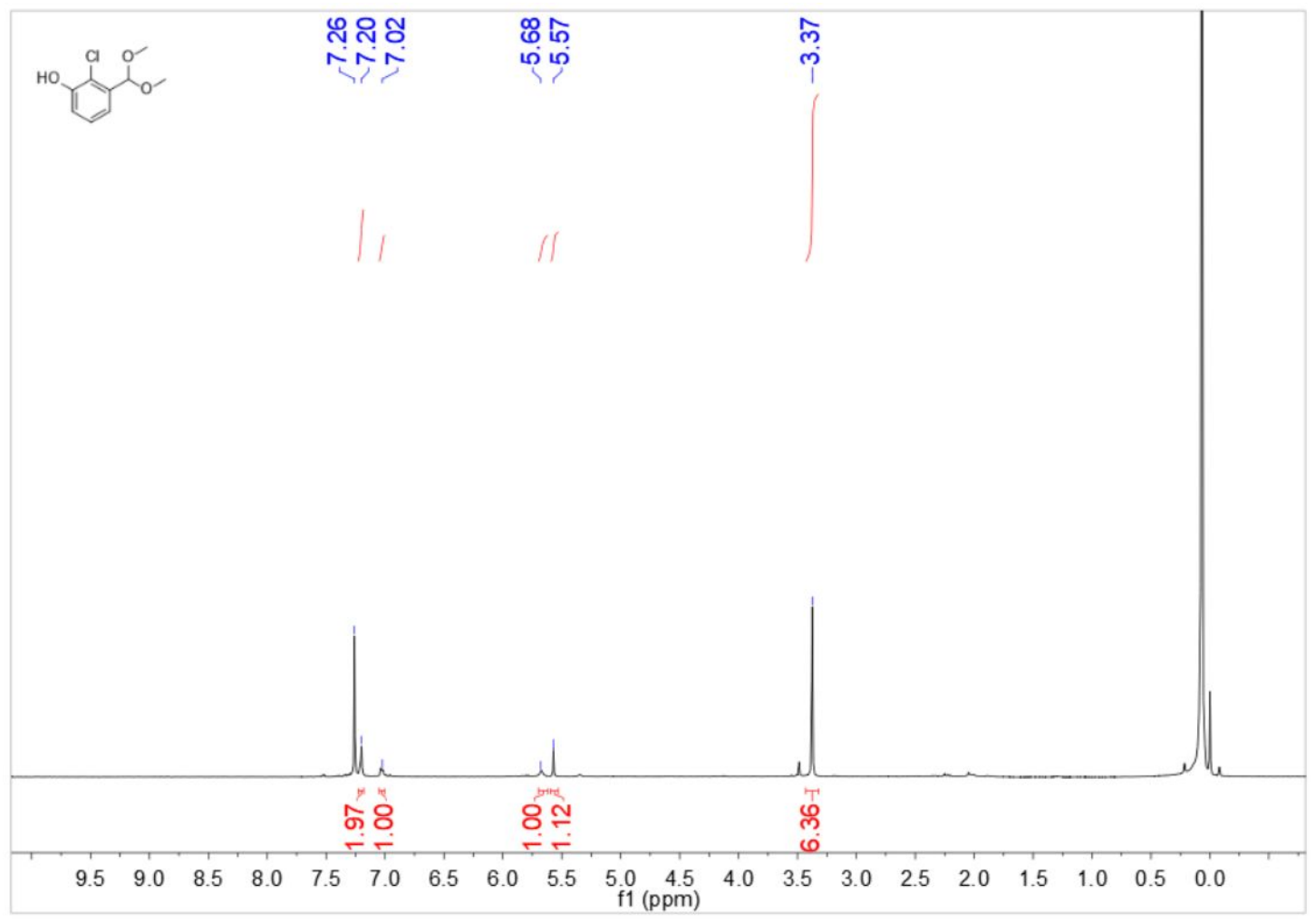

${ }^{1} \mathrm{H}$ NMR of compound 1 


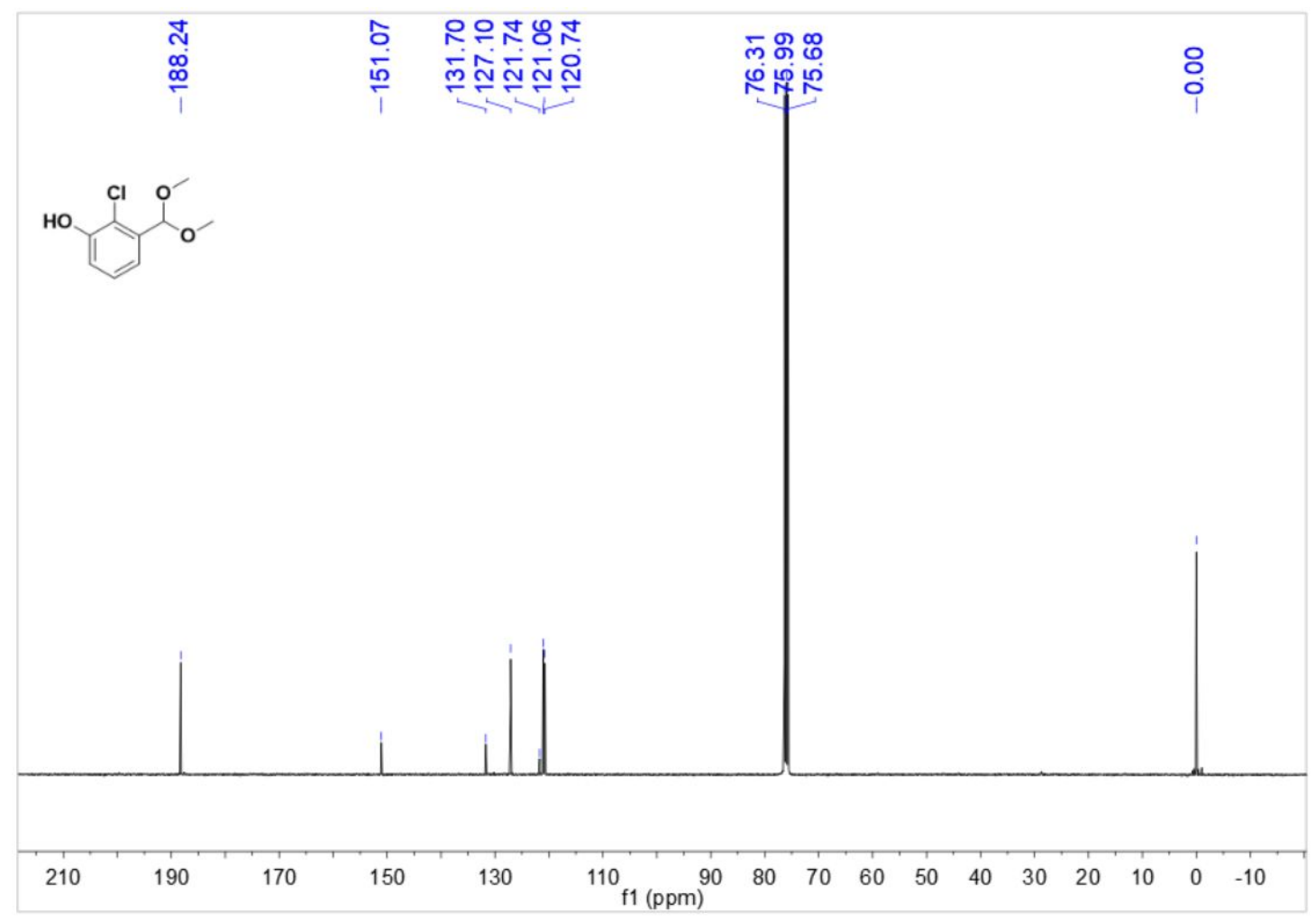

${ }^{13} \mathrm{C}$ NMR of compound 1

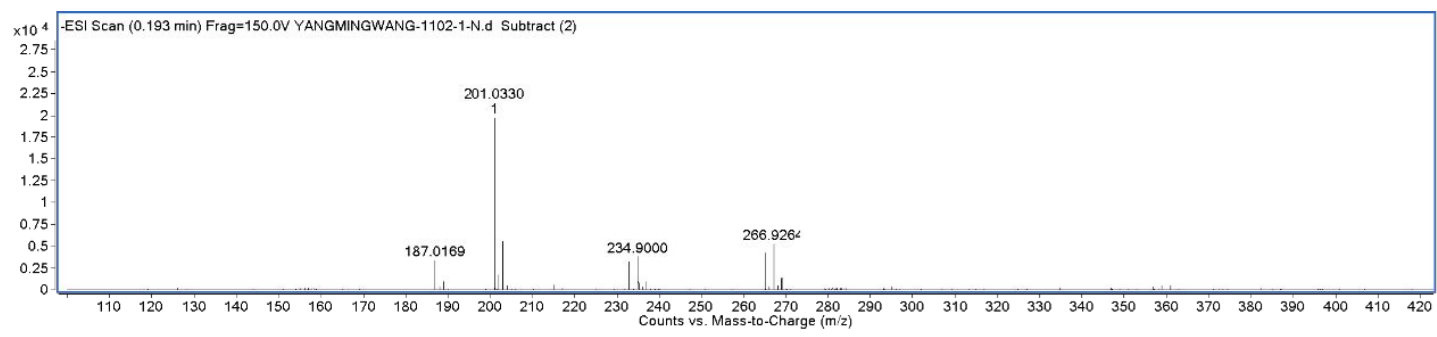

MS of compound 1 


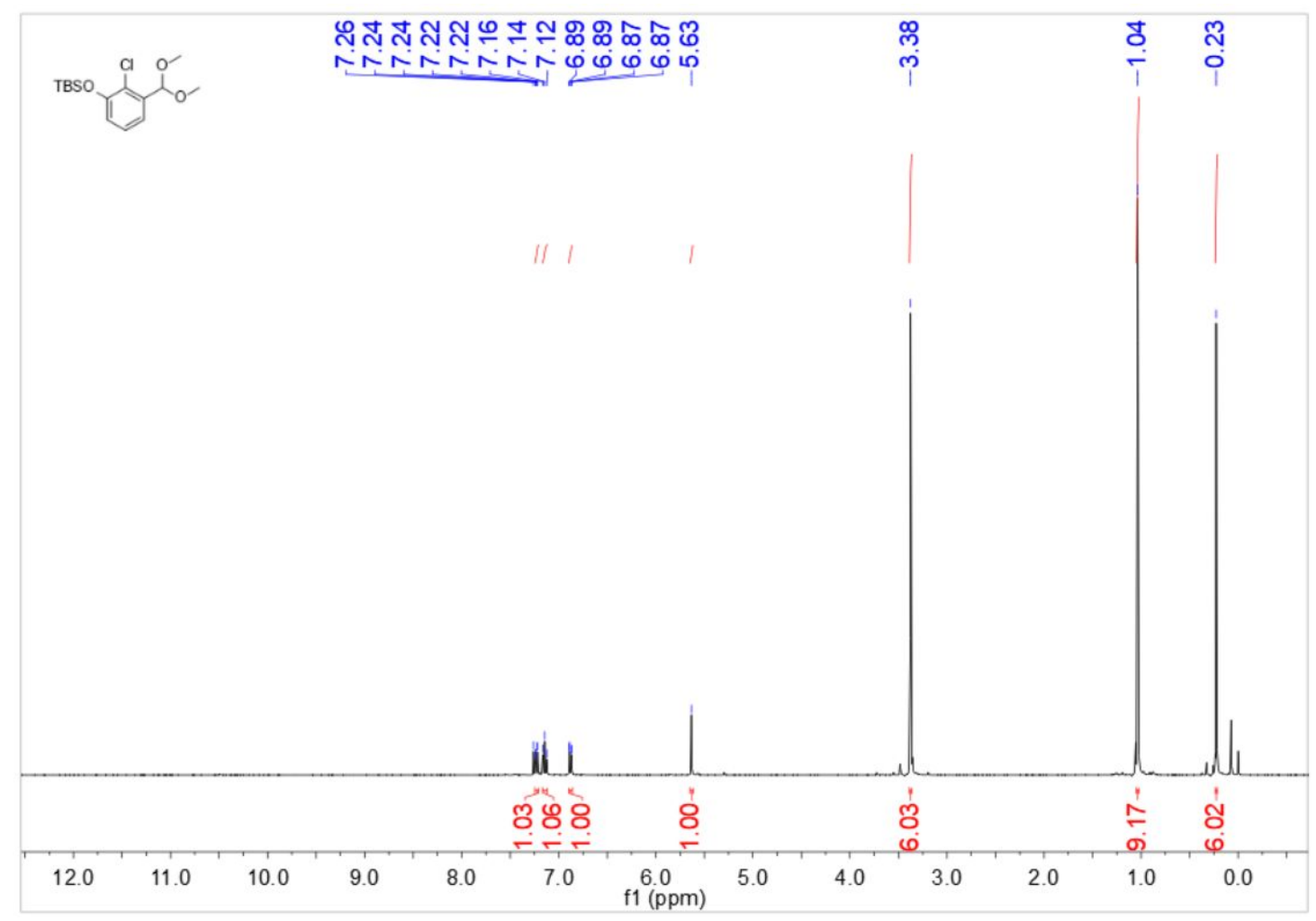

${ }^{1} \mathrm{H}$ NMR of compound 2

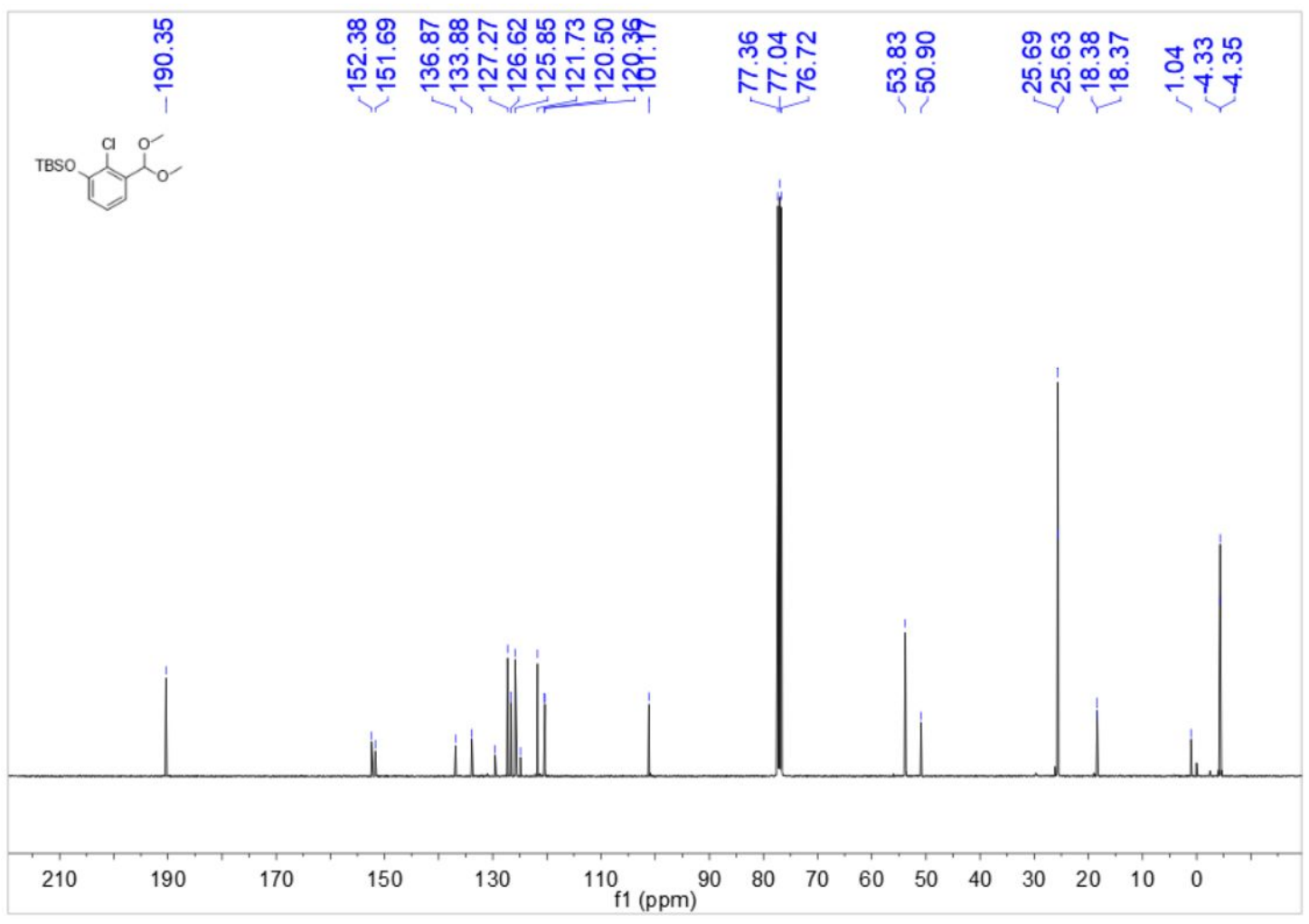

${ }^{13} \mathrm{C}$ NMR of compound 2 
20181107_YangMingwang_TSQ_MS_S1 $=9-25$ RT: $0.08-0.24$ AV: 9 SB: $140.01-0.08,0.45-0.62$ NL: $1.73 E 8$

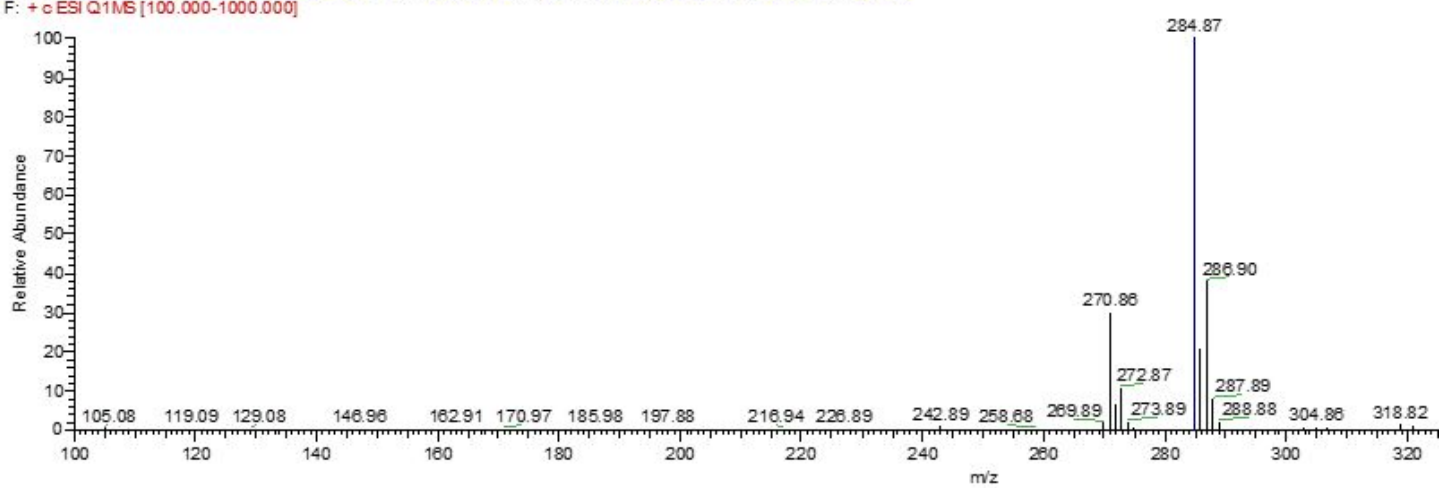

MS of compound 2

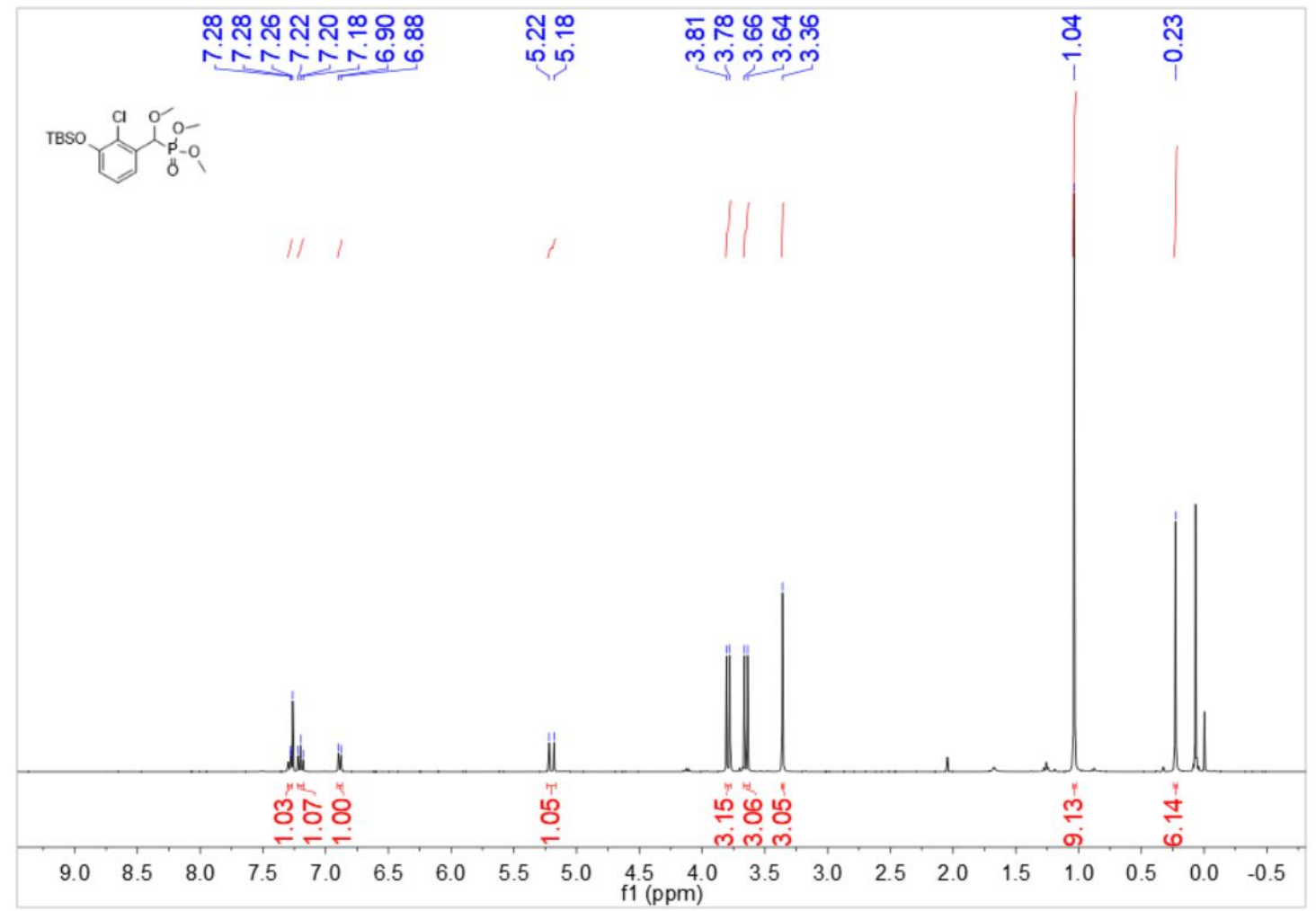

${ }^{1} \mathrm{H}$ NMR of compound 3 


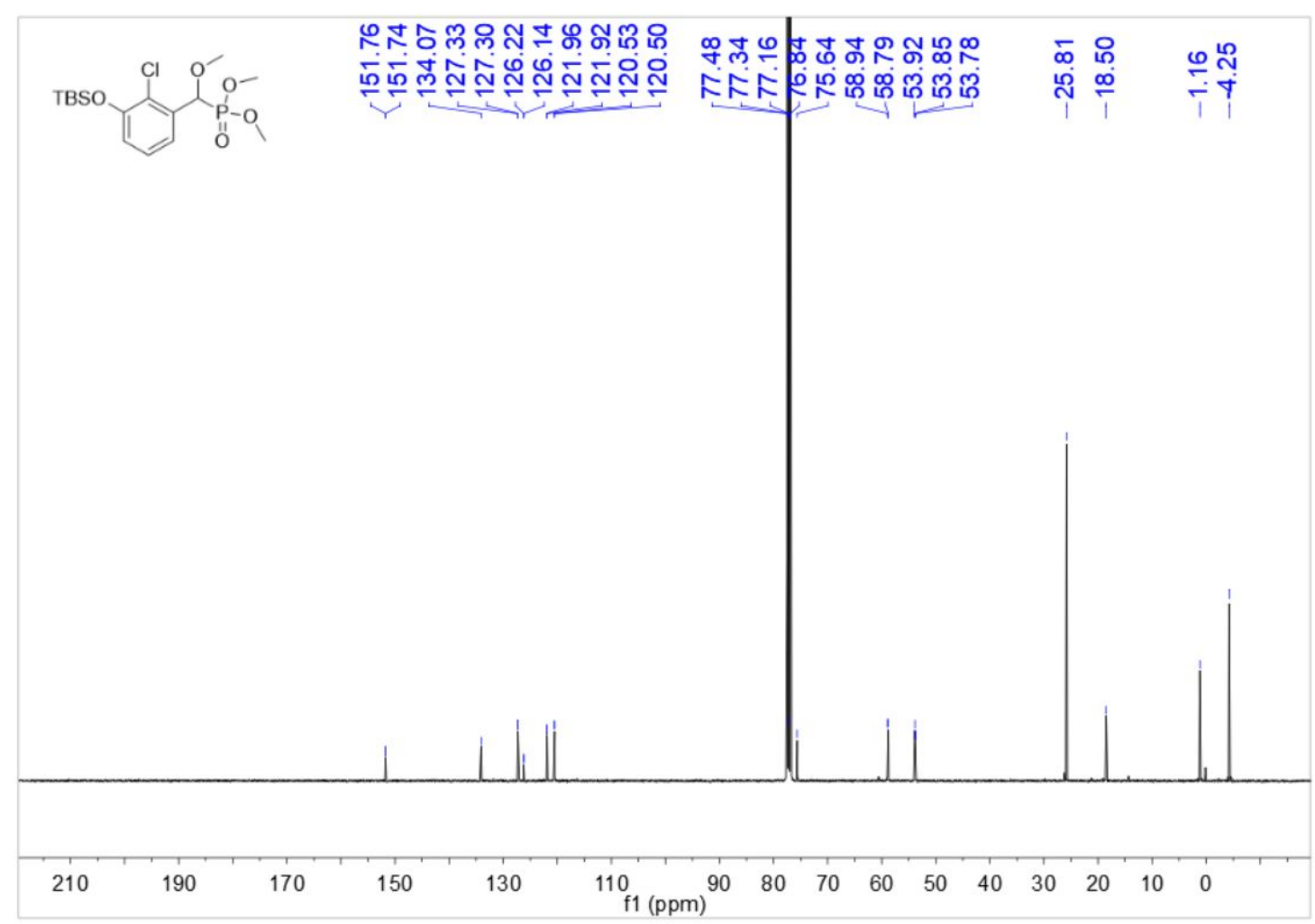

${ }^{13} \mathrm{C}$ NMR of compound 3

20190412_YangMingwang_TSQ_MS_S3 \#10-31 RT: 0.10-0.29 AV: 11 SB: $160.00-0.09,0.53-0.74$ NL: 2.79E8

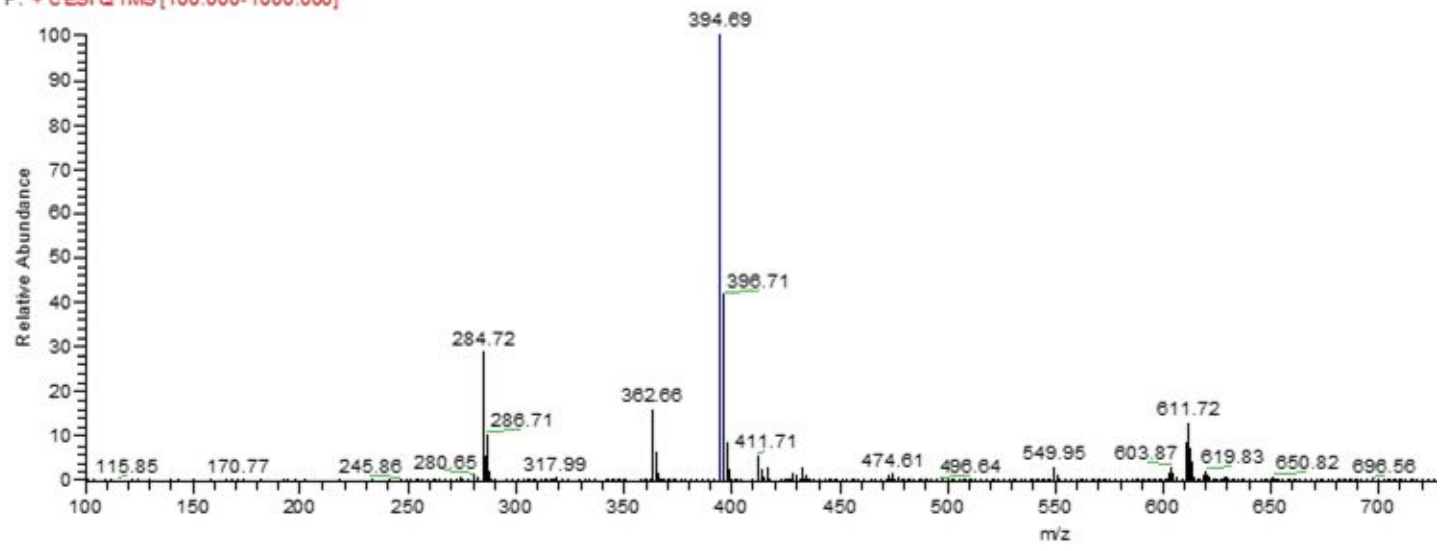

MS of compound 3 


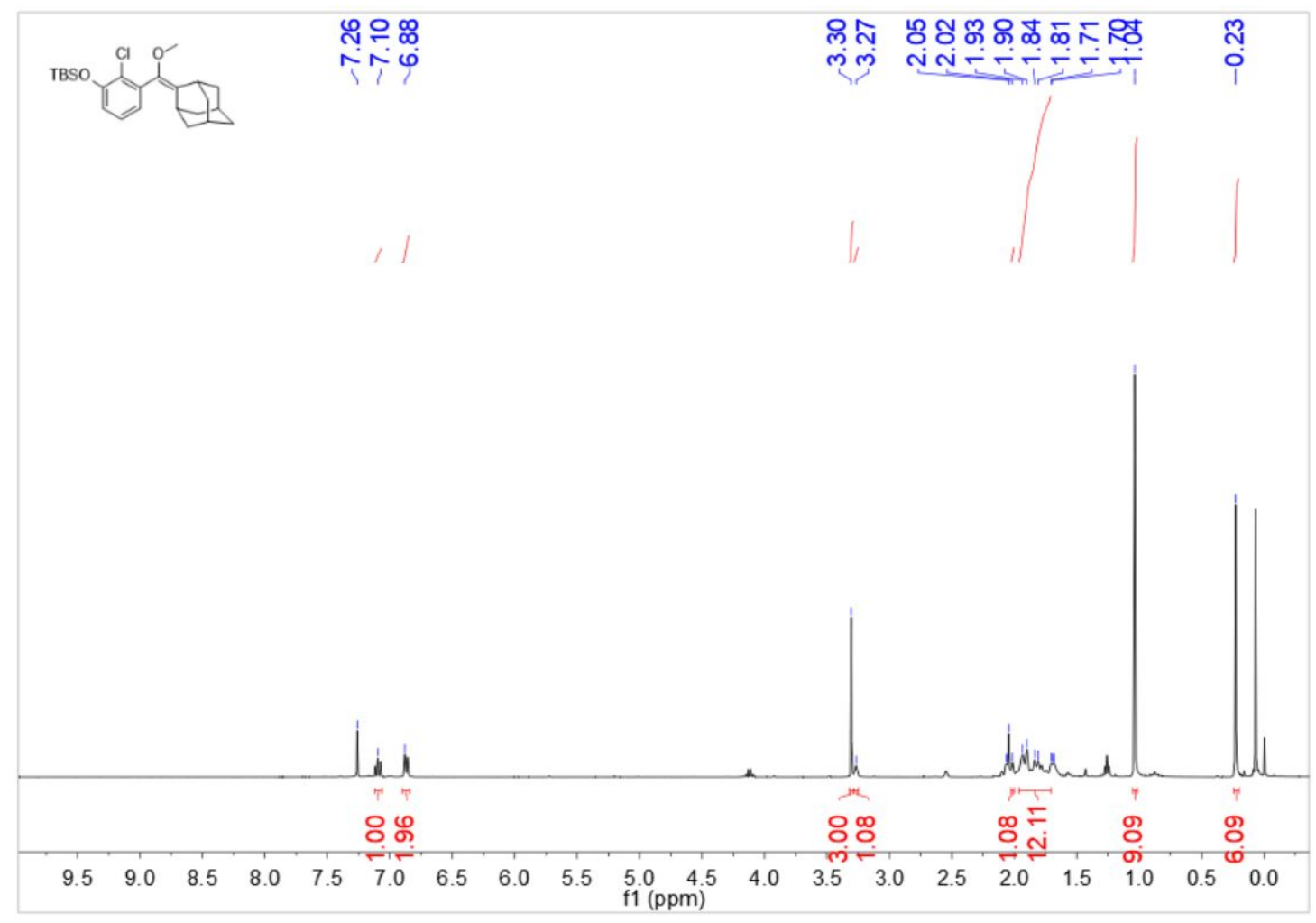

${ }^{1} \mathrm{H}$ NMR of compound 4

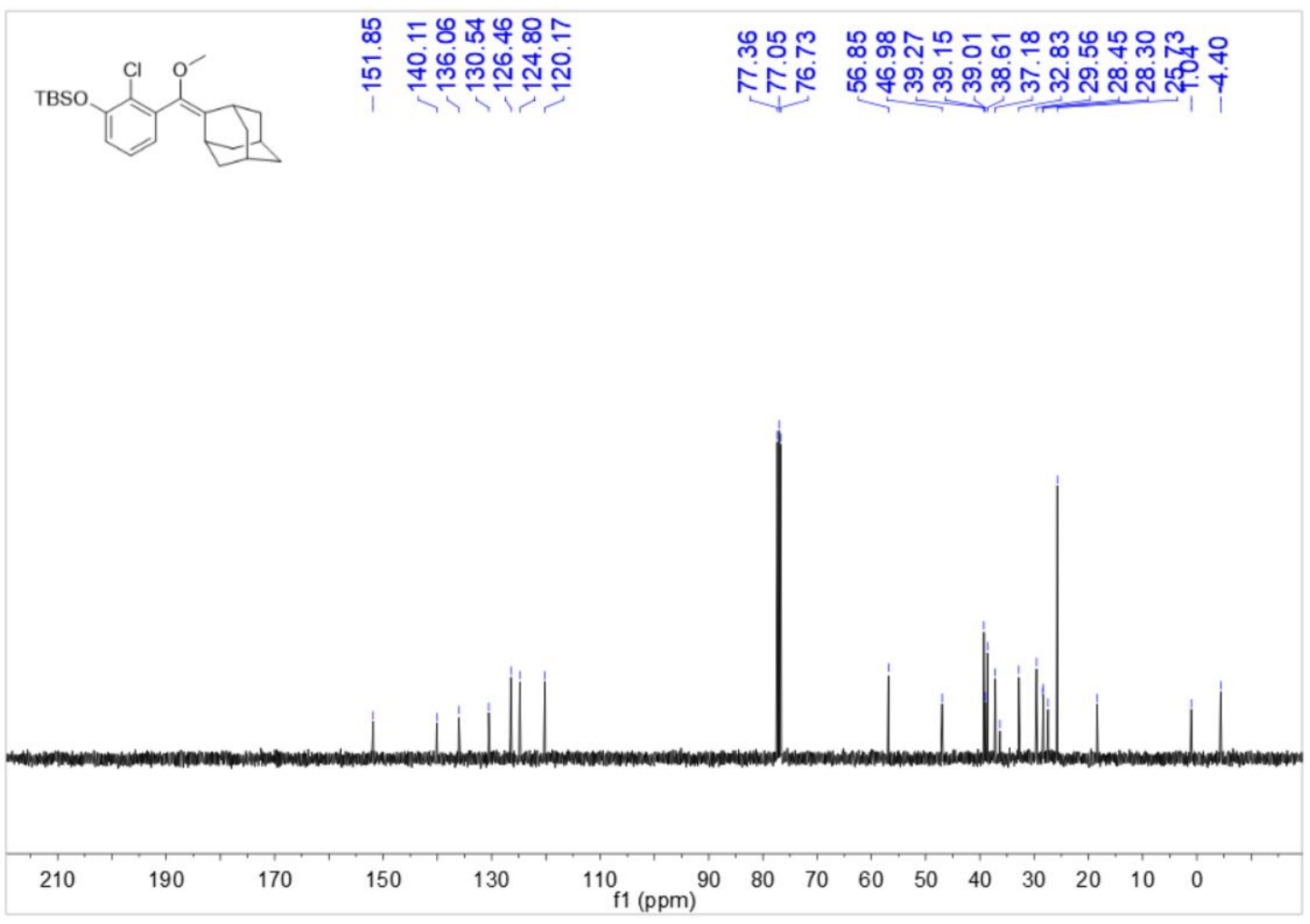

${ }^{13} \mathrm{C}$ NMR of compound 4 


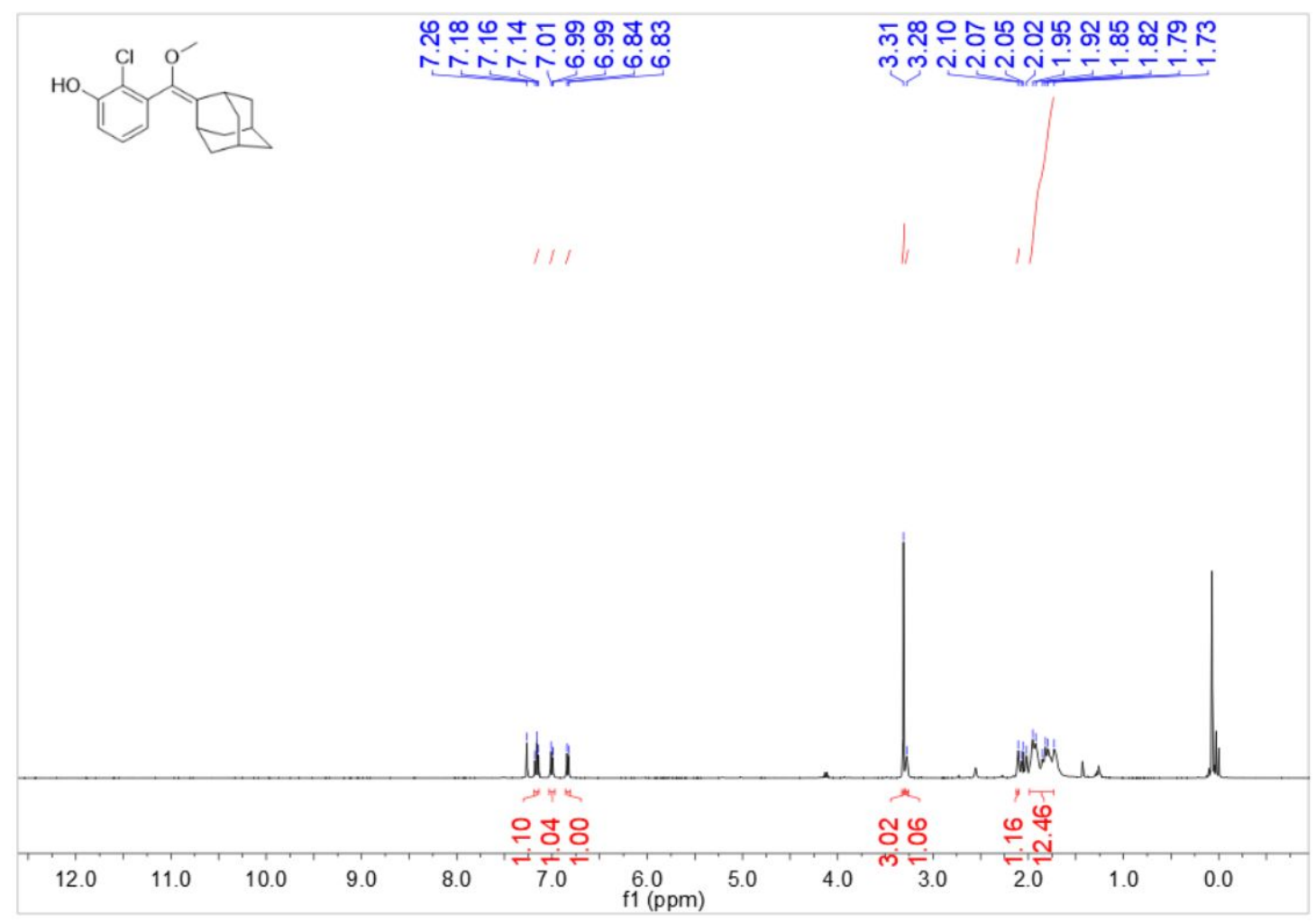

${ }^{1} \mathrm{H}$ NMR of compound 5

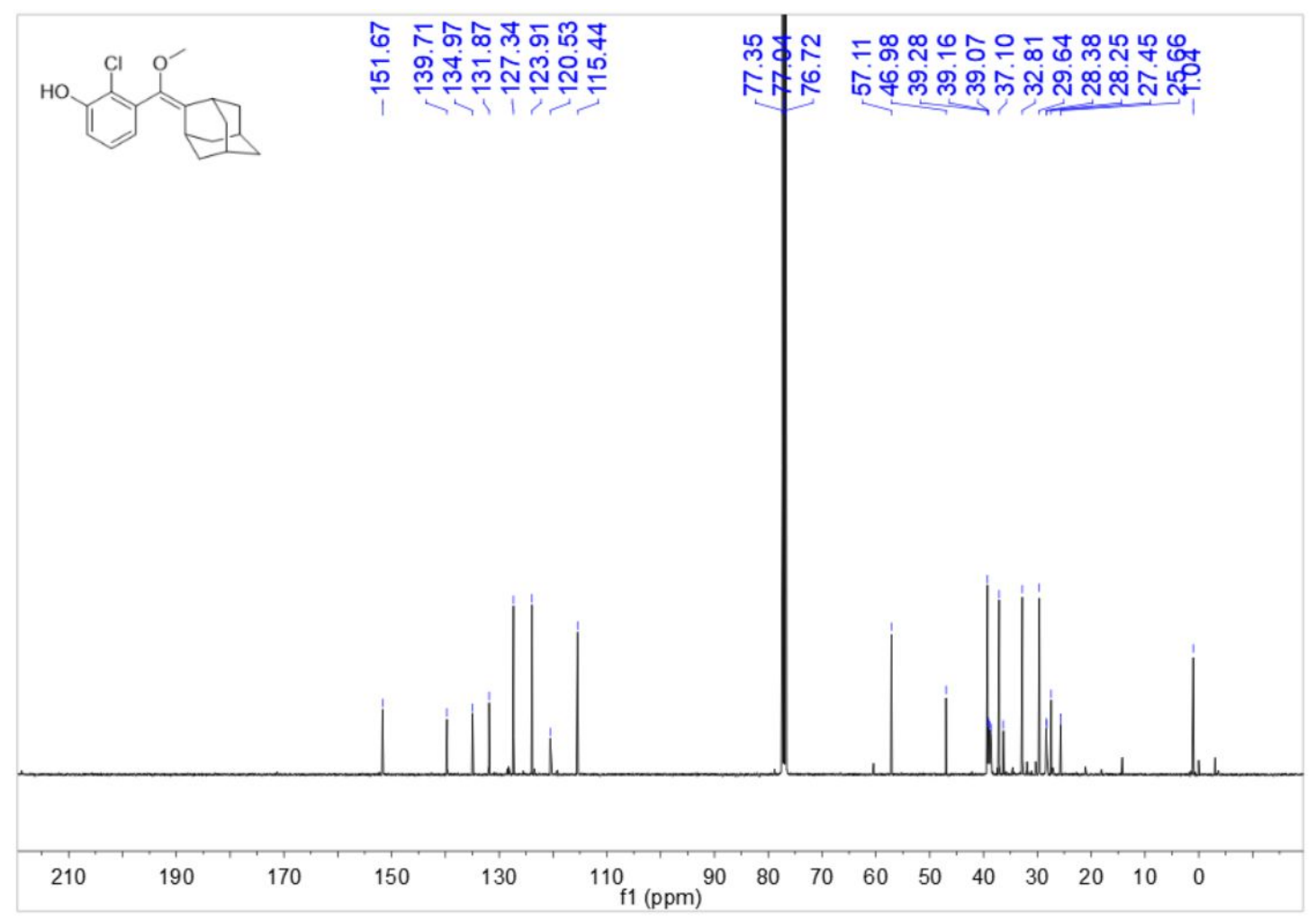

${ }^{13} \mathrm{C}$ NMR of compound 5 
20190412_YangMingwang_TSQ_MS_S1 \#8-24 RT: $0.07-0.23$ AV: 9 SB: 18 0.01-0.08, 0.61-0.87 NL: $5.08 E 7$ F: - C ESI Q1MS [100.000-1000.000]

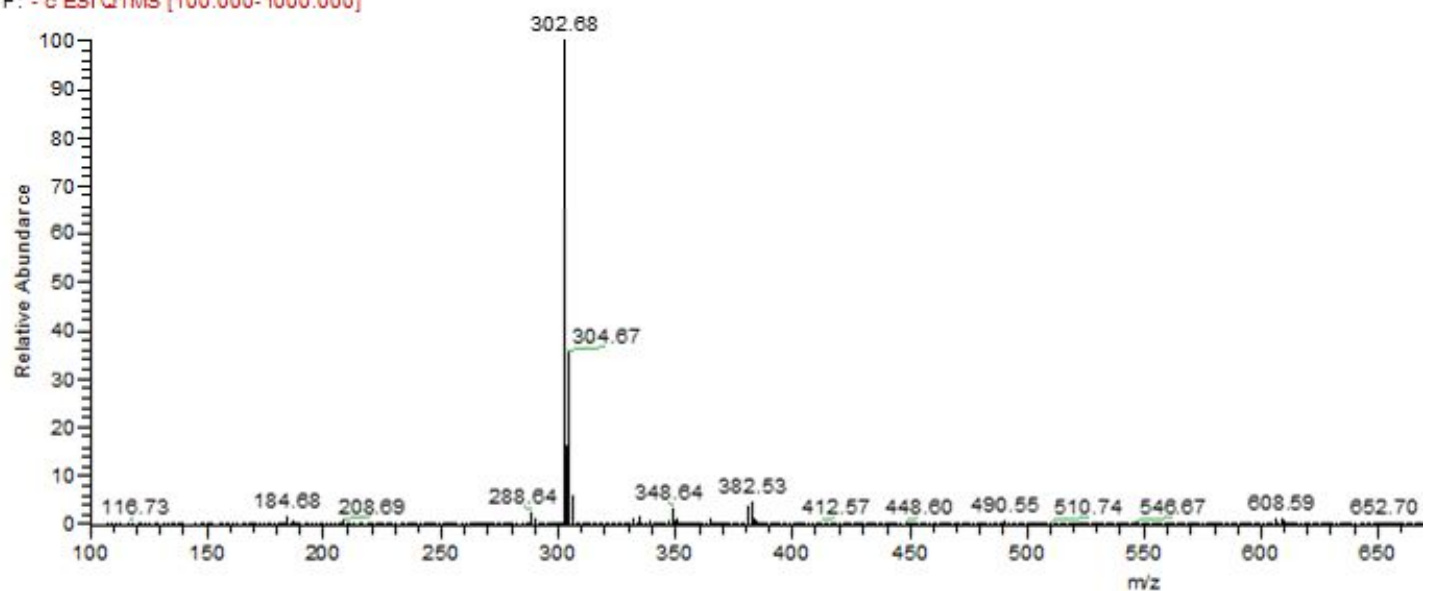

MS of compound 5

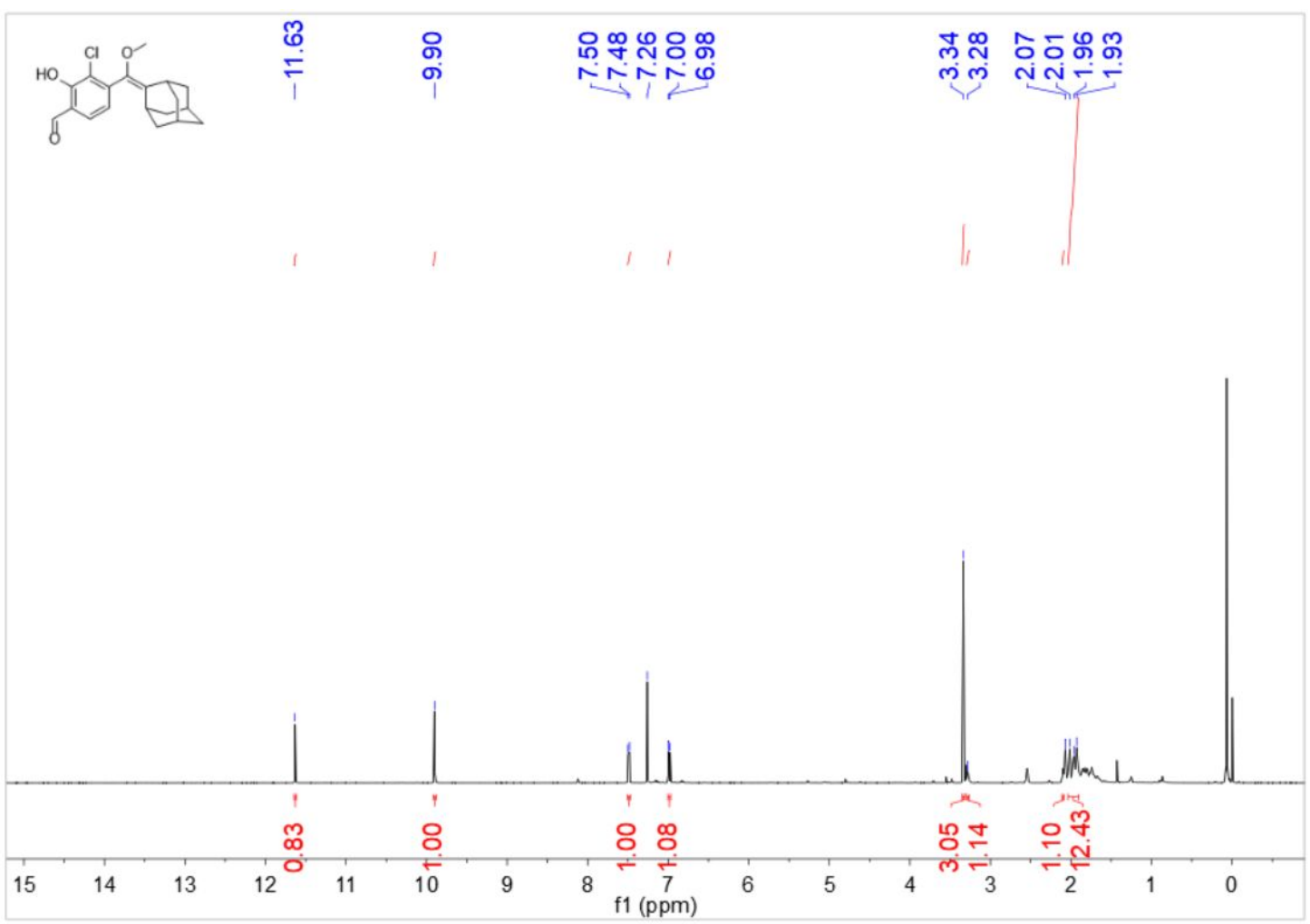

${ }^{1} \mathrm{H}$ NMR of compound 6 


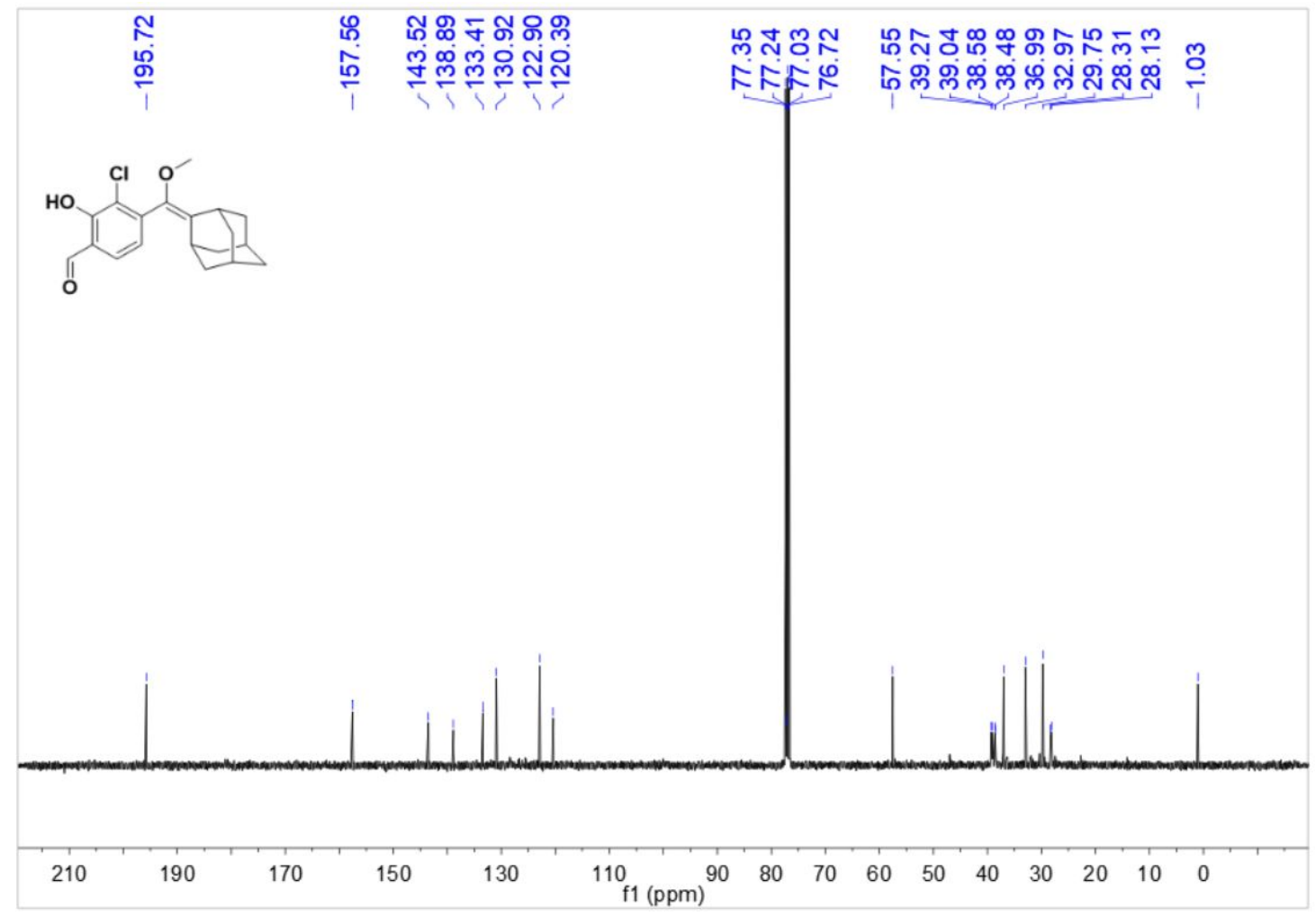

${ }^{13} \mathrm{C}$ NMR of compound 6

20181129_YanglMingwang_TSQ_MS_S1 \#9-29 RT: 0.09-0.26 AV: 10 SB: 15 0.01-0.09, 0.44-0.62 N: 6.56 E6 F: - c ESI Q1MS [100.000-1000.000]

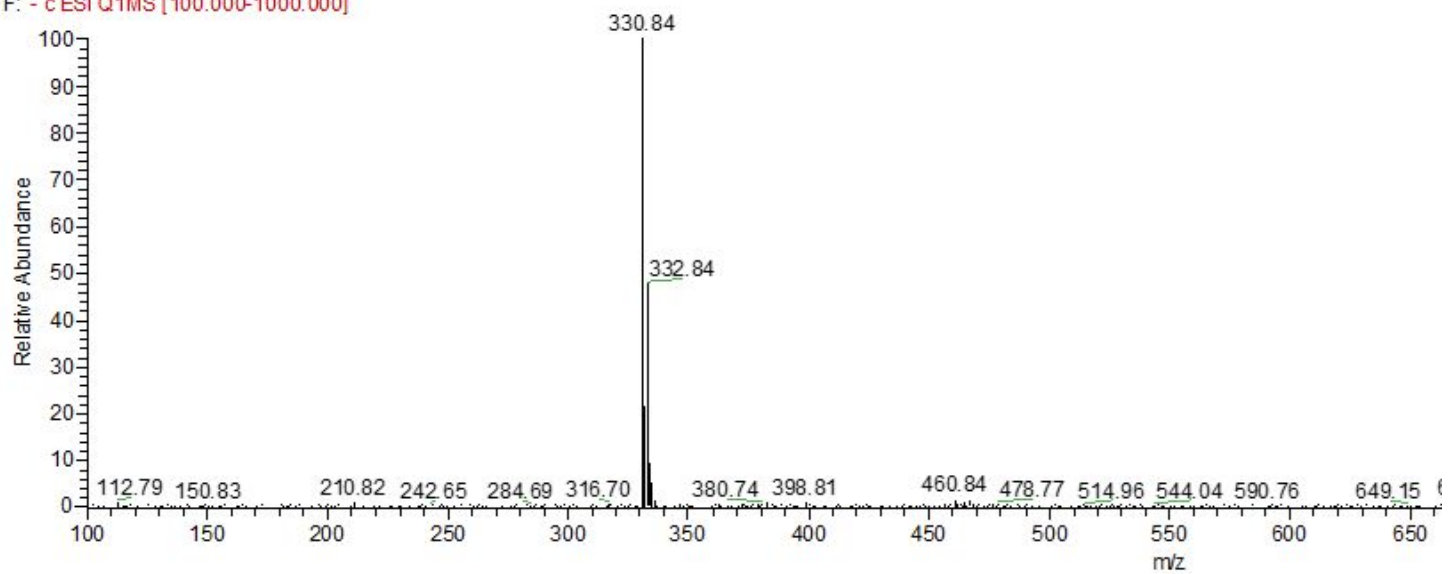

MS of compound 6 


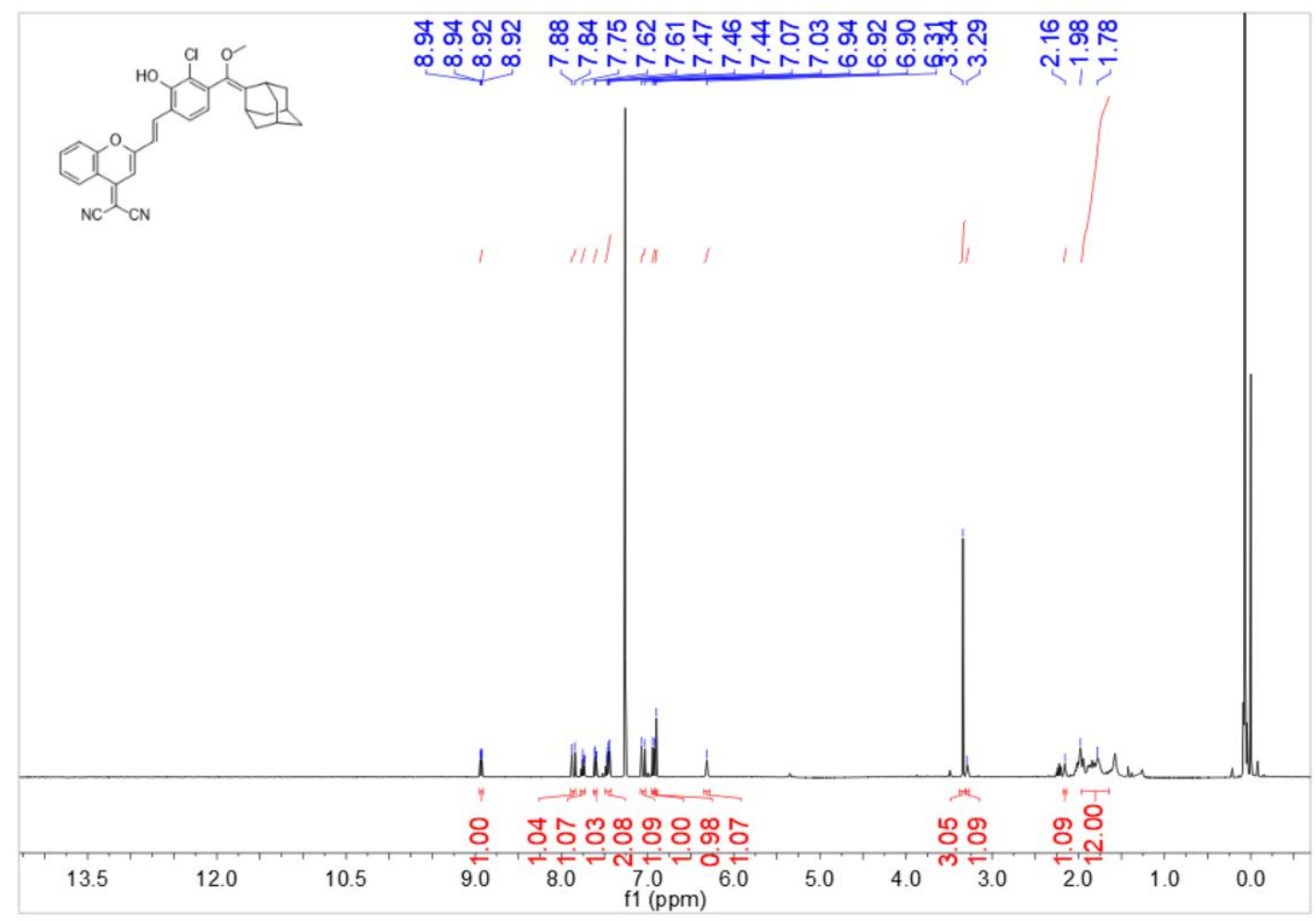

${ }^{1} \mathrm{H}$ NMR of probe CL-SO

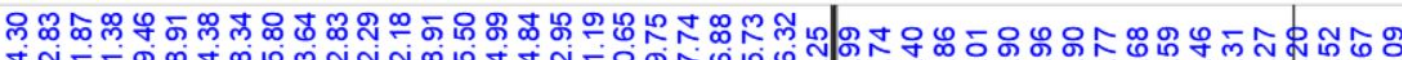

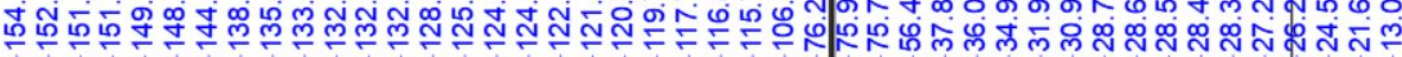

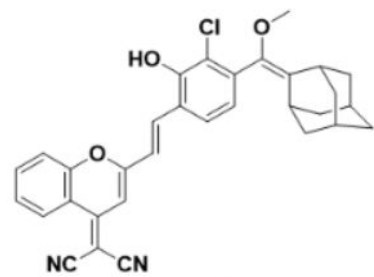

210

190

170

150

110

90

8070

$60 \quad 50 \quad 40$

${ }^{13} \mathrm{C}$ NMR of probe CL-SO 


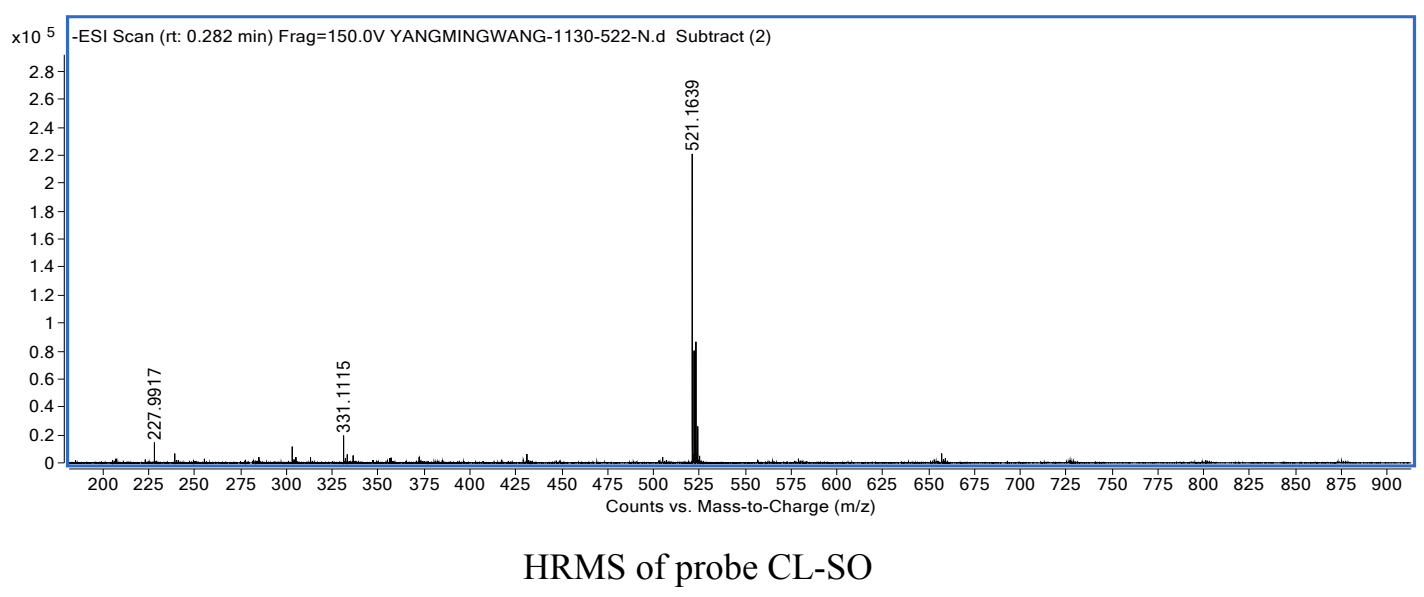

\section{References}

S1 A. Thompson, K. A. Canella, J. R. Lever, K. Miura, G. H. Posner and H. H. Seliger, Chemiluminescence mechanism and quantum yield of synthetic vinylpyrene analogs of benzo[a]pyrene-7,8-dihydrodiol. J. Am. Chem. Soc., 1986, 108, 4498-4504.

S2 Oushiki, D.; Kojima, H.; Terai, T.; Arita, M.; Hanaoka, K.; Urano, Y.; Nagano, T. Development and Application of a Near-Infrared Fluorescence Probe for Oxidative Stress Based on Differential Reactivity of Linked Cyanine Dyes. J. Am. Chem. Soc. 2010, 132, 2795-2801.

S3 Kundu, K.; Knight, S. F.; Willett, N.; Lee, S.; Taylor, W. R.; Murthy, N. Hydrocyanines: A Class of Fluorescent Sensors That Can Image Reactive Oxygen Species in Cell Culture, Tissue, and In Vivo. Angew Chem. Int. Edit. 2009, 48, 299-303.

S4 Maeda, H.; Yamamoto, K.; Kohno, I.; Hafsi, L.; Itoh, N.; Nakagawa, S.; Kanagawa, N.; Suzuki, K.; Uno, T. Design of a Practical Fluorescent Probe for Superoxide Based on ProtectionDeprotection Chemistry of Fluoresceins with Benzenesulfonyl Protecting Groups. Chem-Eur. J. 2007, 13, 1946-1954.

S5 Bai, X.; Huang, Y.; Lu, M.; Yang, D. HKOH-1: A Highly Sensitive and Selective Fluorescent Probe for Detecting Endogenous Hydroxyl Radicals in Living Cells. Angew Chem. Int. Edit. 2017, 56, 12873-12877.

S6 N. Hananya, A. E. Boock, C. R. Bauer, R. Satchi-Fainaro, D. Shabat, Remarkable Enhancement of Chemiluminescent Signal by Dioxetane-Fluorophore Conjugates: Turn-ON Chemiluminescence Probes with Color Modulation for Sensing and Imaging. J. Am. Chem. Soc. 2016, 138, 13438-13446.

S7 K. J. Bruemmer, O. Green, T. A. Su, D. Shabat, C. J. Chang, Chemiluminescent Probes for Activity-Based Sensing of Formaldehyde Released from Folate Degradation in Living Mice. Angew. Chem. Int. Edit. 2018, 57, 7508-7512.

S8 Sun, W.; Fan, J.; Hu, C.; Cao, J.; Zhang, H.; Xiong, X.; Wang, J.; Cui, S.; Sun, S.; Peng, X. A two-photon fluorescent probe with near-infrared emission for hydrogen sulfide imaging in biosystems. Chem. Commun. 2013, 49, 3890-3892. 